\title{
Chlamydia trachomatis and Genital Mycoplasmas: Pathogens with an Impact on Human Reproductive Health
}

\author{
Sunčanica Ljubin-Sternak ${ }^{1}$ and Tomislav Meštrovićc ${ }^{2}$ \\ ${ }^{1}$ Teaching Institute of Public Health "Dr Andrija Štampar” and School of Medicine, University of Zagreb, \\ Šalata 3b, 10000 Zagreb, Croatia \\ ${ }^{2}$ Clinical Microbiology and Parasitology Unit, Polyclinic "Dr Zora Profozić”, Bosutska 19, 10000 Zagreb, Croatia \\ Correspondence should be addressed to Sunčanica Ljubin-Sternak; sljsternak@stampar.hr
}

Received 29 September 2014; Revised 9 December 2014; Accepted 11 December 2014; Published 31 December 2014

Academic Editor: Nongnuch Vanittanakom

Copyright (C) 2014 S. Ljubin-Sternak and T. Meštrović. This is an open access article distributed under the Creative Commons Attribution License, which permits unrestricted use, distribution, and reproduction in any medium, provided the original work is properly cited.

\begin{abstract}
The most prevalent, curable sexually important diseases are those caused by Chlamydia trachomatis (C. trachomatis) and genital mycoplasmas. An important characteristic of these infections is their ability to cause long-term sequels in upper genital tract, thus potentially affecting the reproductive health in both sexes. Pelvic inflammatory disease (PID), tubal factor infertility (TFI), and ectopic pregnancy (EP) are well documented complications of $C$. trachomatis infection in women. The role of genital mycoplasmas in development of PID, TFI, and EP requires further evaluation, but growing evidence supports a significant role for these in the pathogenesis of chorioamnionitis, premature membrane rupture, and preterm labor in pregnant woman. Both C. trachomatis and genital mycoplasmas can affect the quality of sperm and possibly influence the fertility of men. For the purpose of this paper, basic, epidemiologic, clinical, therapeutic, and public health issue of these infections were reviewed and discussed, focusing on their impact on human reproductive health.
\end{abstract}

\section{Introduction}

Sexual transmitted infections (STIs) are a major global health problem with an estimated 340 million new cases of "curable" infections occurring each year worldwide [1]. Alongside "curable" diseases that include bacterial, mycological, and protozoal infections that can be treated with appropriate chemotherapeutic agents, millions of additional cases of incurable STIs caused by viruses are also reported [2]. The most prevalent bacterial STIs are those caused by Chlamydia trachomatis (C. trachomatis). Additionally, there is growing evidence of clinical importance of infections caused by genital mycoplasmas that include various Mycoplasma and Ureaplasma species [3]. Although chlamydial and mycoplasmas genital infections are caused by entirely different microorganisms, there are some similarities in pathogenesis, clinical manifestations, and treatment of these infections. Their most important characteristic is the ability to cause acute complications and long-term sequelae in upper genital tract, thus affecting the reproductive health in both sexes [4-6].
The aim of this review is to acknowledge the significance of these preventable and curable infections from basic, epidemiologic, clinical, therapeutic, and public health perspective.

\section{Bacterial Morphology and Pathogenesis}

C. trachomatis have circular genome of $1042 \mathrm{kbp}$, which is approximately a quarter of an E. coli genome [7]. It also contains a cryptic plasmid 7500 bp in length [8]. Plasmid transcriptional activity can contribute to the regulation of chlamydial chromosomal gene expression [8], but direct impact of plasmid gene product on virulence is also a possibility [9]. A detection of cryptic plasmid's nucleic acid is utilized for diagnostic purposes. Mutants with a specific deletion within the plasmid that prevented C. trachomatis detection using a commercially available nucleic acid amplification test were described in Sweden and resulted in a concern about reliable detection methods; still, widespread 
problems and increase in disease severity have not been an issue $[10]$.

C. trachomatis is an obligate intracellular bacterium with a unique life cycle characterized by the transformation of an extracellular, infectious elementary body (EB) in the intracellular, noninfectious, metabolically active reticulate body (RB) and vice versa. The whole cycle and its main pointssuch as initial ligand-receptor contact, endocytosis, and the avoidance of endocytic lysosomal pathway with the crucial role of chlamydial contact-dependent type III secretion system (TTS) in these processes-was previously reviewed by other authors $[11,12]$. Furthermore, it was demonstrated that chlamydial exposure to adverse factors (e.g., penicillins or interferon gamma) induces conversion of $\mathrm{RB}$ into a persistent, aberrant form which does not replicate, has a reduced metabolic activity, but is still viable [13, 14]. This phenomenon is a reversible process and thus could be a possible mechanism of recurrences. Additionally, aberrant forms of RBs, with reduced major outer membrane protein (MOMP) and lipopolysaccharide (LPS) antigens, persist with high production of chlamydial heat shock protein 60 (hsp60) capable of inducing inflammation and scarring, common characteristics of chronic infection [15]. A number of chlamydial virulence factors, such as serovar-defining MOMP and TTS, define the outcome of infection and disease severity. Several types of genetic variation are found in C. trachomatis that impact variability and expression of virulence factors, such as high degree of variability in the exposed portions of MOMP, polymorphic TTS effectors, and amino acid substitutions in pmp autotransporters [16]. These strategies have been demonstrated to foster chlamydial intracellular survival, aid in the evasion of the host immune system, and form the basis for distinct chlamydial disease variations in host tissue tropism [17]. Host genetics also play a role in the disease severity. For example, women who carry specific HLA DQ and IL-10 promoter alleles that modify host immune response were found to develop TFI more frequent than control group [18].

The term "mycoplasma" is often used to refer to any members of the class Mollicutes (for the purposes of this review as well), irrespective of the fact whether they truly belong to the genus Mycoplasma [19]. Additionally, there are number of species in this class which are not clinically relevant, which emphasizes the need to change the generally accepted term in favor of the species. The genital tract is the main site of colonization for six species-Ureaplasma urealyticum, Mycoplasma hominis, Mycoplasma genitalium, Mycoplasma penetrans, Mycoplasma primatum, and Mycoplasma spermatophilum [19]. The latter two are considered nonpathogenic for humans. Akin to other Mollicutes, they do not possess a cell wall but instead are enclosed by a trilayered cell membrane [20]. They are smaller than conventional bacteria, both in their cellular dimensions and genome size [21]. Their genomes range from $947 \mathrm{kbp}$ (711 genes) for $U$. urealyticum to $580 \mathrm{kbp}$ genome (485 genes) for M. genitalium: the latter represents the smallest genome of a self-replicating organism presently known, demonstrating how little genetic material is actually needed to foster microbial life [22]. Several factors are important in the pathogenesis of genital mycoplasmas: (a) expression of specific adhesion proteins; (b) antigenic variation; (c) production of enzymes; and (d) facultative intracellular localization. Although the adhesions of ureaplasmas have not been characterized entirely, the evidence suggests that the receptors are sialyl residues and sulfated compounds [23]. Variable adherence-associated antigen (Vaa) and $\mathrm{MgPa}$ adhesion protein are believed to be major adhesion proteins in M. hominis and M. genitalium, respectively [24, 25]. Additional surface proteins, such as OppAl, are also believed to be involved in cytoadherence and may also induce ATP leakage from cells, resulting in their apoptosis. The MB (multiple-banded) antigen, a major antigen recognized during human ureaplasmal infections, and Vaa display high-frequency phase and size variation [26]. A subset of repetitive DNA elements homologous to the $\mathrm{MgPa}$ adhesion gene is thought to contribute to variation in the protein of the $\mathrm{MgPa}$ adhesion gene [27]. The variation of surface antigens is important factor in evasion of host immune response and may be related to persistence of these organisms at invasive sites. Production of enzymes such as the nuclease of $M$. genitalium or urease and immunoglobulin A1 of $U$. urealyticum provides basic compounds for their synthesis and damages the local immunity [28-30]. Facultative intracellular localization is now demonstrated for $M$. fermentans, $M$. penetrans, and $M$. genitalium, which may be responsible for protecting the organisms from antibodies and antibiotics, contributing to disease chronicity and possibly hinders in vitro culture [31-33].

\section{Epidemiology}

The WHO estimates that over 90 million new cases of $C$. trachomatis infections are diagnosed each year [34]. In 2012, there were 1422976 new cases of C. trachomatis infection reported in United States, revealing the rate of 456.7 per 100,000 people [35]. In the developed countries, an estimated chlamydia prevalence is highest in young heterosexual adults under 25 years of age, ranging from 3 to $6 \%$ among those who are sexually active $[36,37]$.

Similar to other countries, C. trachomatis prevalence in Croatia varies among different type of investigated population and depending on laboratory methods used for chlamydia detection. Population characteristics with a significant impact on chlamydia prevalence include age, sex, ethnicity, clinical observation (e.g., asymptomatic versus symptomatic status), and high-risk behavior (e.g., men who have sex with men-MSM). Recent study that investigated nationally representative, multistage stratified probability sample of Croatian young women and men aged 18-25 revealed 5.3\% and $7.3 \%$ prevalence, respectively. Detection was performed using Roche real-time PCR assay in urine samples [38]. Earlier study that investigated $C$. trachomatis prevalence in asymptomatic men and men with symptoms of acute urethritis revealed the prevalence of $2.9 \%$ and $18.5 \%$, respectively. C. trachomatis infection was diagnosed by enzyme immunoassay antigen detection method [39]. Study also revealed that the highest prevalence of $35.3 \%$ in symptomatic 
patients was observed among the youngest age group (1825 years). Conflicting prevalence results of $C$. trachomatis were observed in patients with chronic prostatitis. In the period from 2003 to 2005, C. trachomatis was proved to be a causative pathogen in $19.3 \%$ of patients treated in one Croatian university hospital using cell culture method [40], whereas only 0.88 patients in the same hospital proved to be infected with chlamydia in the period from 2010 to 2013 when Abbott RealTime PCR test was used [41].

Akin to C. trachomatis, genital mycoplasmas can be transmitted through direct interaction between hosts-venereally through genitogenital or orogenital contact and vertically from mother to child (either in utero or at birth) [19]. Ureaplasma spp. and M. hominis have been isolated from cervicovaginal specimens in $40-80 \%$ and $21-53 \%$ of women who are asymptomatic and sexually active, respectively [23]. This prevalence is somewhat lower in males [23]. M. genitalium appears to be detected with highest prevalence in men with nongonococcal, $C$. trachomatis negative urethritis [42]. The prevalence of the organism in this group of patients ranged from $13 \%$ to $42 \%$, and in asymptomatic men from $0 \%$ to $15 \%$ [43]. The prevalence of M. genitalium in symptomatic women ranged from 5 to $42 \%$ [44]. More than $20 \%$ of infants may be colonized by Ureaplasma spp., and infants born before term are more likely to harbor the organisms, with colonization burden declining after third month of age [23]. Less than 5\% of children and $10 \%$ of nonsexually active adults are colonized with genital mycoplasmal microorganisms [19].

Research on incidence and prevalence of genital mycoplasmas in Croatia is scarce. Ružman et al. did a study on 456 pregnant women in Eastern Croatia and found positive cervical culture for U. urealyticum, M. hominis, or both in 164 (36\%) of examinees [45]. One hundred and fiftyfour $(93.9 \%)$ of them had $U$. urealyticum, only $2(1.2 \%)$ had M. hominis, and only 8 (4.9\%) had both agents. In a recent study which included 1370 symptomatic and asymptomatic women of reproductive age, Ureaplasma spp. were identified by cultivation in 424 (34.4\%) of them [46]. Subsequential genotyping of positive samples identified $U$. parvum as the predominant Ureaplasma species (92.6\%). The prevalence of M. genitalium in symptomatic men in Croatia is $2.3 \%$ [47].

\section{Impact on Female Reproductive Health}

The most common clinical manifestation of $C$. trachomatis infection in women is mucopurulent cervicitis and/or urethritis [48]. Approximately half of all infected women have the infection both in cervix and the urethra, one-third in the cervix only and approximately one-quarter in the urethra only [49]. Unfortunately, a majority of infections (up to 70\%) in women are asymptomatic [50], thus posing a risk for unrecognizing and subsequently not treating the infection. Left untreated, infection can lead to several complications with serious consequences for female reproductive health [51]. Spread of C. trachomatis from the urethra and endocervix to the upper genital tract causes pelvic inflammatory disease (PID). Herzog et al. in their mathematical model study have demonstrated that estimated fraction of chlamydia infected women that develop PID is 10\% [52]. Another study conducted by Price et al. has calculated the probability of $16 \%$ that an episode of $C$. trachomatis infection will result in PID [53].

PID includes broad range of clinical syndromes: endometritis, salpingitis, tuboovarian abscess, pelvic peritonitis, periappendicitis, and perihepatitis. Diagnosis is usually based on the clinical findings, but, in severe cases of PID, laparoscopic evaluation and intra-abdominal bacterial samples are helpful for the confirmation of diagnosis and accurate microbiologic testing [54]. Acute PID can progress into a chronic form of the disease, characterized with scarification and appearance of adhesions, and further complicate with TFI and ectopic pregnancy (EP). After a single episode of PID, the relative risk for TFI is approximately $10 \%$, and each recurrent episode of PID doubles the risk-making it almost $40 \%$ after three or more episodes [55].

Recent case-control study from two tertiary health care facilities from Benin in Nigeria demonstrated significantly higher C. trachomatis titers in woman with EP (48\%) when compared to a control group (16.3\%) [56]. In another casecontrol study, group of researchers from Iran looked for C. trachomatis in fallopian tube tissue of women with and without EP using PCR. They have detected C. trachomatis in $11.9 \%$ of patients with EP and none in the control group [57].

Similar to the observation that the majority of C. trachomatis infections in the lower female genital tract are asymptomatic, subclinical PID associated with chlamydia is also common. It represents a silent threat to female reproductive health, as it was shown that women with diagnosed subclinical PID have a $40 \%$ reduced incidence of pregnancy compared to women without subclinical PID [58]. In addition, study conducted on clinically asymptomatic women undergoing investigation of infertility and laparoscopy showed evidence of C. trachomatis infection in $15.9 \%$ of patients, detected by either PCR in fallopian tubes washings or EIA serology [59]. It is thought that $C$. trachomatis infection is major cause of female infertility today [60].

During pregnancy, C. trachomatis may cause chorioamnionitis and preterm delivery [61]. Djukić et al. demonstrated positive C. trachomatis antibodies and/or antigen in amniotic fluid obtained during cesarean section in $9.6 \%$ and $3.8 \%$ samples, respectively [62]. C. trachomatis infection in pregnant women also increases the risk of low birth weight and perinatal mortality [63]. Prospective study from Belgium has shown significant association between chlamydial infection and chorioamnionitis and lower birth weight and severe neonatal infection [64]. Study from Finland clearly demonstrated that seropositivity to $C$. trachomatis in women detected during pregnancy is associated with perinatal complications [65].

The risk for vertical transmission of chlamydia is between $60 \%$ and $70 \%$ and follows the infant's passage through the birth canal, which can result in neonatal sepsis [66]. However, there is some evidence that vertical transmission can also occur in utero, since newborns delivered by cesarean sections have also been born infected and with intact membranes $[67,68]$. 
C. trachomatis has also been found in all of the tissues of a newborn child, which suggest its invasive capacity $[66,69]$. Chlamydial DNA is increasingly being detected in different tissues of neonates who died of sepsis and neonates with infection (without isolated pathogen) who died during their first week of life. In a recent study from Brazil, HernandezTrejo et al. demonstrated that $C$. trachomatis could play a role in the development of severe infection and in early neonatal death, similar to that observed with $M$. hominis [66]. End-point and real-time PCR of the omp1 gene was used in this study to recognize the presence of chlamydial DNA in the paraffinized organ samples of the dead neonates. Severe neonatal infection corresponded to genotype $\mathrm{D}$ of $C$. trachomatis.

Finally, C. trachomatis infection is associated with cervical hypertrophy and induction of squamous metaplasia, thus may be a contributing cofactor in development of cervical neoplasia [70, 71]. It was shown that women with positive serum antibodies to $C$. trachomatis had a significantly increased risk for cervical cancer [72]. Study from Denmark has shown that repeated $C$. trachomatis infections increase the risk of cervical intraepithelial neoplasia (grade 3 or worse) among women with prevalent, as well as persistent highrisk HPV infection [73]. It seems that C. trachomatis generates an environment favorable for malignant transformation by perturbing host chromatin, DNA double-strand breaks repair, and cell-cycle regulation [74]. However not all studies could prove the association between chlamydial infection and cervical cancer development [75]. Furthermore, much of the data that support this association have been confounded by HPV coinfection. Therefore, the role of C. trachomatis infection in development of cervical cancer has to be further investigated and elucidated.

Genital mycoplasmas are also associated with the harmful effects on reproductive health of women and adverse pregnancy outcomes. The adverse influence of $M$. hominis on the epithelial cells of fallopian tubes in laboratory conditions was already established four decades ago [76], and this microorganism has been isolated from the endometria and fallopian tubes of about $10 \%$ of women with salpingitis [77]. In a study from Denmark on 304 infertile women, a significant correlation between TFI and seropositivity of $M$. hominis has been found and patients with TFI had a 2.13-fold higher risk of having antibodies against $M$. hominis compared with patients with normal tubes [78]. Tyagi also found that the presence of antibodies of $M$. hominis was more common in infertile women with tubal disorders [79]. Still, several newer studies did not find a positive correlation of $M$. hominis with infertility $[6,80-82]$.

Infertility associated with $U$. urealyticum was initially reported by Kundsin [83] and subsequently supported by other studies showing a high frequency of infection with Ureaplasma spp. in infertile women [84, 85]. Nonetheless, although Ureaplasma spp. have been isolated directly from affected fallopian tubes, it was mostly as a part of polymicrobial infection [86]. That result, along with negative serology findings and studies of inoculation of nonhuman primates and fallopian tube organ cultures, does not support a causal relationship for ureaplasmas in PID or TFI [19]. Therefore we still do not have an answer whether this particular genital mycoplasma could account for a small proportion of infertility cases or whether the relation in question is only coincidental.

The preponderance of reports implicates $U$. urealyticum and $M$. hominis in prematurity-linked conditions and Ureaplasma spp. are thought to be the most common organisms isolated from infected amniotic fluid and placentas [87]. In a Czech study that included 225 women with preterm premature rupture of membranes, $68 \%$ of them had cervical colonization by $U$. urealyticum compared to $17 \%$ among control patients, and $28 \%$ of them were colonized by $M$. hominis compared to $15 \%$ of controls [88]. M. hominis was also found to be a risk factor for preterm birth after 24 weeks of gestation [89]. A study of almost 2000 women in Belgium found a preterm birth rate of $4.9 \%$, and $53.6 \%$ of those with premature delivery showed colonization with Ureaplasma spp. [90].

Another study of 150 women with premature rupture of membranes reported that U. urealyticum was present in $96 \%$ of subjects, compared to only $32 \%$ of women who did not experience membrane rupture [91]. A study of placental cultures from Japan found that among 151 placentas from pregnancies that ended with spontaneous preterm birth before 32 weeks of gestation, 63 were culture positive for Ureaplasma spp. and $83 \%$ of these showed histologic chorioamnionitis, whereas only $30 \%$ of culture negative placentas showed signs of chorioamnionitis [92]. Authors from Austria indicated that there is a dose-dependent inflammatory response inside the amniotic cavity to $U$. parvum and that this is related not only to premature membrane rupture, preterm labor, and histologic chorioamnionitis, but also to bronchopulmonary dysplasia and early onset sepsis in the baby [93]. Kataoka et al. indicated that a detection of $U$. parvum in a vagina was associated with late abortion and early preterm birth [94].

Since Taylor-Robinson et al. demonstrated in 1987 that primates inoculated with M. genitalium develop both salpingitis and lower genital tract pathology [95], a myriad of other studies supported the theory that this bacterium has a role as an etiologic factor in PID. Bjartling et al. did a nested case-control study in Sweden among women undergoing the termination of pregnancy [96]. Of the 49 women with PID, $12.2 \%$ were positive for M. genitalium (compared with a $2.4 \%$ positivity in the control group); hence the organism in this study was strongly associated with posttermination PID, and a causal relationship was suggested. In a different study from the same authors on a heterogeneous population of women attending a gynecological outpatient service, $M$. genitalium was a strong and independent risk factor for both PID and cervicitis [97].

Positive association of M. genitalium with short-term PID treatment failure was also described by Haggerty et al. on samples from the PID Evaluation and Clinical Health (PEACH) Study $[98,99]$. In contrast, one prospective study following female sex workers in Kenya over a period of 36 months failed to find an association of $M$. genitalium infection with PID [100]. Still, taking into account the persistent nature of M. genitalium (comparable to other STDs), it is possible that the duration of the follow-up period and high 
percentage of loss to follow-up were inadequate to detect incident PID. It has to be noted that the clinical diagnosis of PID includes several variable signs that frequently do not correlate with laparoscopic findings, which certainly contributes to inconsistency among PID studies and could influence the associations with $M$. genitalium infection.

No association between $M$. genitalium and EP was established thus far [101], and its role in adverse pregnancy outcomes is still unclear [102]. Several studies have shown an independent association of M. genitalium with preterm birth [103-105], although no other syndromes have been linked to the infection with this organism [106, 107]. In a group of 915 women from the United Kingdom, Oakeshott et al. demonstrated an association between M. genitalium and preterm birth [103]. Edwards et al. found that M. genitalium was independently associated with spontaneous preterm delivery on a cohort of 137 women [104].

Research on M. genitalium as a cause of female infertility has shown a high correlation. Two studies from Denmark have found a significant association between women with specific serum antibodies to this bacterium and laparoscopically established tubal infertility. Clausen et al. examined sera for antibodies to M. genitalium by immunoblotting from 308 women presenting to an infertility clinic in Denmark using laparoscopically confirmed tubal occlusion as the diagnostic criterion [108]. The results revealed that the relative risk of tubal factor infertility in women with M. genitalium was 3.8. A strong antibody response against $M$. genitalium without the signs of current or chronic infection was found in women with TFI in the study of Svenstrup et al., indicating that preceding infections with this microorganism may have caused permanent injury and occlusion of the fallopian tubes [109].

In a study by Grześko et al. of 74 Polish women attending an infertility clinic, M. genitalium was detected by PCR more frequently in cervical swabs from infertile patients when compared to healthy, fertile women [110], indicating that endocervical swabs can forecast upper tract infection. Baczynska et al. have proven that the presence of $M$. genitalium in the human fallopian tubes organ culture affected the epithelium and resulted in cilia destruction, although the damage was not so extensive when compared to the damage caused by C. trachomatis [111].

\section{Impact on Male Reproductive Health}

Approximately half of the men infected with C. trachomatis show no symptoms of infection [112]. Nongonococcal urethritis is the most common clinical presentation of $C$. trachomatis infection in males, which can be complicated with epididymitis and orchitis-especially in young men [39, 113-116]. Although chlamydia is well recognized and accepted cause of male urethritis, epididymitis, and orchitis, the role of C. trachomatis in pathogenesis of prostatitis is controversial. There are studies that suggest that $C$. trachomatis is the causative agent in one-fifth to one-third of patients with prostatitis [40, 117-119]. In our opinion, chlamydial prostatitis should be diagnosed carefully, considering the symptoms, clinical findings, obtained clinical sample (e.g., semen, urine, expressed prostatic secretion, and prostatic tissue), and employed laboratory methods. Our recent study demonstrated that the significance of C. trachomatis in etiology of prostatitis has been overemphasized, mostly as result of using nonspecific methods for laboratory diagnosis of $C$. trachomatis infection [41]. In addition, chronic prostatitis caused by chlamydia could be very tricky for laboratory diagnosis and treatment, due to the evidence of persistent forms that have been reported after treatment of chronic prostatitis with antimicrobial drugs [120].

Ascending chlamydial infection can potentially result in scarification and occlusion of the canalicular system of male genital tract and thus influence male fertility, but it seems to be a very rare phenomenon $[49,121]$. More important is the possible influence of $C$. trachomatis infection on sperm quality. A number of studies investigated the relationship between $C$. trachomatis infection and semen quality with contradictory results [122-125]. Nevertheless, some of them suggest that exposure to $C$. trachomatis can affect sperm function and induce premature sperm death [126, 127].

It is estimated that $15 \%$ of male infertility is related to genital tract infection [128]. Among the causative factors, $U$. urealyticum is one of the most frequently encountered species [129]. Since 1967, the ureaplasmas have been linked to the etiology of male infertility [130], especially after Friberg and Gnarpe [131] demonstrated for the first time a higher frequency of ureaplasmas in the semen of men with unexplained infertility (76\%) when compared with fertile men (19\%). The presence of U. urealyticum could cause dysfunction of accessory sex glands, and the abnormality of their secretion can lead to a change of seminal characteristics [132]. Xu et al. reported that U. urealyticum infection reduced spermatozoa motility and increased their abnormality rate [133]. A study from Poland found that deteriorated semen density, sperm vitality, and progressive motility of spermatozoids were associated with U. urealyticum [134]. This infection was also associated with higher semen viscosity and lower semen $\mathrm{pH}$ value, and sperm concentration was lower in positive subjects in the study of Wang and coauthors [129].

Recent studies also point to the detrimental effects of $U$. urealyticum on the conventional sperm parameters. The presence of this microorganism was related to lower mean sperm concentration and lower vitality of spermatozoa in the study of Liu et al. which included a total of 621 infertile and 615 fertile men [125]. Progressive motility and vitality were significantly lower in men positive to this microorganism than in men without it in a study from the Republic of Korea conducted in a fertility clinic [135]. Statistically significant decrease in the integrity of sperm plasma membrane in patients with $U$. urealyticum has also been recently demonstrated by Chinese researchers [136]. In addition, recent study from Montenegro showed that treating the infection resulted in the increase of the sperm concentration itself with the significant improvement of progressive motility, although being without the effect on the viability of the spermatozoa [137].

Several of the abovementioned studies researched the influence of $M$. hominis on semen parameters as well. In 
a study from Lee et al. low total motility and total motile sperm count were significantly related to the presence of this mycoplasma [135]. In a study among 250 unselected infertile men, there were a significantly higher percentage of patients with oligoasthenoteratozoospermia or asthenozoospermia alone in the group infected with $M$. hominis compared to noninfected, infertile patients [138]. The presence of $M$. hominis DNA in semen samples was associated with low sperm concentration and abnormal sperm morphology in a study from Tunisia, although the mean values of $\mathrm{pH}$, total volume, vitality, motility, and polymorphonuclear count were not significantly related to the detection of genital mycoplasmas [139]. Sequential sectioning of spermatozoa infected with $M$. hominis revealed the intracellular location of this bacterium within cytosolic spaces of head and midpiece regions, suggesting that this kind of interaction could lead to subtle damage that can have implications for long-term male or couple's infertility [140].

More research on M. genitalium regarding the effect on semen parameters and male infertility is needed. Thus far this microorganism has been isolated from semen specimens and its ability to attach to human spermatozoa has been shown by X-ray microscopy $[141,142]$. In a study from Gdoura et al., the concentration of spermatozoa among the male partners of infertile couples with M. genitalium DNA in semen specimens was significantly lower when compared to male partners without this microorganism [139]. On the other hand, in a study on 127 infertile and 188 fertile men in Kuwait, Al-Sweih et al. concluded that no significant association between M. genitalium and diminished fertility exists, although they did note that genital mycoplasmas appeared to negatively influence quality of the semen [143].

\section{Laboratory Diagnosis}

Since both chlamydial and mycoplasma infections may not show specific symptoms and are often indistinguishable or asymptomatic, laboratory diagnosis is necessary in order to establish the correct etiology.

6.1. Culture Methods. As chlamydia is an obligate intracellular pathogen, it requires living cells for its multiplication. Isolation in cell culture traditionally has been considered as a "gold standard" for many years, but with the advent of molecular methods its role has been challenged. Such culture method is technically demanding, labor-intensive, cumbersome, expensive, and-most importantly-less sensitive when compared to the nucleic acid amplification tests (NAATs) [144]. Specificity of the culture method approaches $100 \%$ when fluorescein-labeled monoclonal antibodies are used for the detection of inclusions (Figure 1). Sensitivity in experienced laboratory approaches $85 \%$ compared with NAATs [145]. Another disadvantage of this method is that it requires perfectly organized cold chain of transportation in order to deliver viable microorganism to the laboratory [146]. However, because an isolation of living microorganism is the definitive method for the diagnosis, culture remains the method of choice in terms of medicolegal investigations

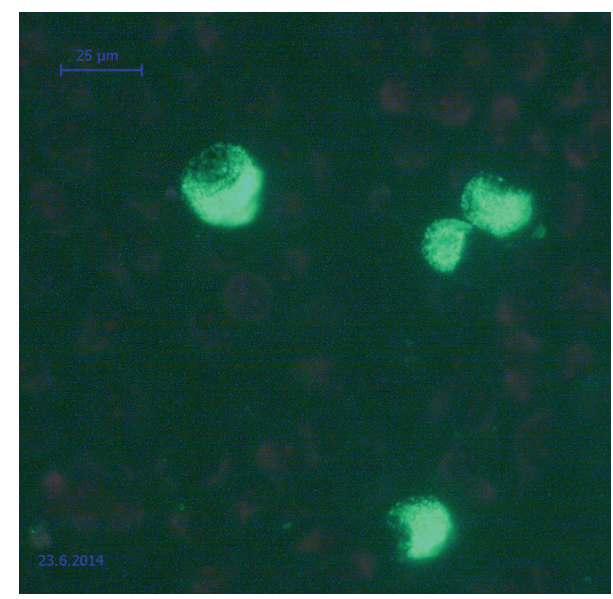

FIGURE 1: Chlamydia trachomatis inclusions in McCoy cell culture detected by fluorescein labeled monoclonal antibodies against lipopolysaccharide antigen. Note the lens-like uncolored region on the one side of each inclusion that presents displaced nucleus of infected cell.

and follow-up after completed therapy [145]. Additionally, it also serves for determining the antimicrobial sensitivity of $C$. trachomatis $[147,148]$.

As with chlamydia, culture is also regarded as a "gold standard" for the detection of recoverable organisms like $M$. hominis and Ureaplasma spp.; nevertheless, a low sensitivity when compared to polymerase chain reaction (PCR) assays has been reported repeatedly $[149,150]$. Culture is labourintensive and time consuming, as it entails the use of an enrichment broth for up to seven days, followed by subculturing onto solid media $[150,151]$. The development of commercially available diagnostic assays, which are based on liquid broth cultures, provides faster and more user friendly alternatives to conventional culture methods for the detection of genital mycoplasmas [47, 151]. Enriched liquid broth that contains urea, arginine, and phenol red indicator is observed for eventual changes of the colour and allows subculture to solid media with subsequent recovery and identification of both $M$. hominis and Ureaplasma spp. [47]. The culture of $M$. genitalium is even more difficult and time consuming, and no liquid broth culture methods exist, which is the reason why cultivation of this organism is employed for research purposes only [152]. All of that hinders the possibilities for microbial susceptibility testing of genital mycoplasmas.

6.2. Antigen Detection Methods. There are several commercially available antigen detection methods for diagnosis of chlamydial infection with two main approaches: direct fluorescein test (DFA) and enzyme linked immunosorbent assay (ELISA). Those tests do not require stringent conditions for specimen transportation. The DFA test is the only diagnostic test that permits simultaneous assessment of specimen adequacy by visualization of epithelial cells present in the smear [146]. In relation to culture, the sensitivity and specificity of DFA tests that use antibodies to MOMP are $80-90 \%$ and 98-99\%, respectively [153]. Most of the ELISA tests detect 
chlamydial LPS which is more soluble than MOMP, although it can cross-react with other gram-negative bacteria [154]. Their sensitivity and specificity range from 62 to $96 \%$ and from 86 to $99 \%$, respectively, in comparison to cell culture [155]. Antigen detection techniques have not been developed for genital mycoplasmas [19].

6.3. Molecular Methods. Development of the NAATs has been the most important advancement in the field of chlamydial diagnosis due to their high sensitivity; potentially, they are capable of detecting as little as a single gene copy [156]. Such characteristic enabled the usage of noninvasive specimens like urine. Transportation is also not a crucial issue, as molecular testing does not require living organism. All these characteristics were an important enhancement, especially for screening purposes. Currently, three NAATs dominate molecular diagnostics of $C$. trachomatis: Roche Cobas TaqMan CT assay that targets both the cryptic plasmid and the omp1 gene, the Abbott RealTime CT m2000 PCR that targets two parts of the cryptic plasmid, and the Gen-Probe Aptima Combo 2 that targets the 23S rRNA molecule [157]. Comparing to other NAATs, the Roche TaqMan assay shows superior specificity (100\%), but with sensitivity estimated at $82.4 \%$. All of the mentioned assays can successfully detect the new variant strain of $C$. trachomatis, described in Sweden in 2006 [10].

PCR is the most broadly applied NAAT for detection of genital mycoplasmas as well and has been adapted to identify antimicrobial resistance determinants or to evaluate genetic relatedness of clinical isolates [158]. Modern laboratories today have eliminated conventional PCR in favour of real-time PCR, using the Roche LightCycler for detection and identification of all the major human mycoplasma species due to its advantages in accuracy, quantitation, and turnaround time [159]. The enhanced specificity of real-time PCR (compared with conventional PCR) is chiefly because of the use of a third oligonucleotide probe that binds to the target sequence, thus minimizing the potential crossreactions [160]. Publications describing real-time PCR for detection and characterization of $M$. hominis and Ureaplasma spp. have used previously mentioned Roche LightCycler 2.0, as well as Applied Biosystems Prism 7900HT and the BioRad iCycler iQ [159]. For slow-growing species, such as $M$. genitalium, molecular-based detection is the only practical way for rapid diagnosis, although commercial assays available for detection (AmpliSens Mycoplasma genitalium-EPh PCR kit and Euroclone Duplic $\alpha$ RealTime) are still pending FDA approval and are still mostly used for research purposes [47].

Molecular technology also enables simultaneous detection of more than one microorganism. Multiplex real-time PCR was found to be an equivalent or superior modality for the diagnosis of STIs [161]. In a recent study by Korean authors, Anyplex II multiplex real-time PCR for seven different pathogens had $100 \%$ sensitivity and high specificity for the detection of $C$. trachomatis, M. genitalium, and M. hominis, and it was also useful for discriminating between $U$. urealyticum and U. parvum [162]. Simultaneous direct identification of $C$. trachomatis, genital mycoplasmas, and several other genital microorganisms in voided urine using multiplex PCR-based reverse line blot assays had also been recently described [163]. Sexually transmitted infection profiling (STIP) assay that detects 18 sexually transmitted infections (among them C. trachomatis, M. genitalium, $M$. hominis, M. spermatophilum, U. urealyitcum, and U. parvum) using a multiplex PCR followed by Luminex bead-based hybridisation has been described with an overall concordance of $95-100 \%$ with commercially available quantitative PCR tests [164].

6.4. Serology. Generally, serological tests in the diagnosis of genital tract infections caused by $C$. trachomatis are not useful, as the antibodies elicited by C. trachomatis are long lived and positive antibody test usually cannot distinguish previous from current infection. However, serology may have some diagnostic significance in investigations of woman with PID, TFI, and spontaneous miscarriage [165], and negative result may have predictive value in infertile women [166].

Higher anti-cHSP60 antibody responses in women with tubal occlusion and TFI caused by $C$. trachomatis have been demonstrated in contrast to women without tubal pathology $[167,168]$. These findings have led to the development of a commercial ELISA screening test based on cHSP60 (Medac, Hamburg, Germany) [169]. Still, studies evaluating the diagnostic potential of the Medac cHSP60 ELISA test have revealed conflicting results, thus the ability of this assay to distinguish various $C$. trachomatis disease stages may be limited $[169,170]$. Australian study by Collet et al. demonstrated that the use of four chlamydial antigens (CT157, CT423, CT727, and CT396) could potentially facilitate earlier diagnoses in women suffering from tubal occlusion and other pathologies of the upper genital tract [171]. They were found to be capable of discriminating between the infection and disease sequelae, such as tubal infertility. Sensitivity of $80 \%$ and specificity of $86 \%$ have been noted for this assay.

Serological test methods for Ureaplasma spp., M. hominis, and M. genitalium include enzyme immunoassay, microimmunofluorescence, and metabolism inhibition, but the ubiquity of these microorganisms in healthy people makes the interpretation of antibody titers against them challenging [19]. As the most serious outcome of tubal scarring caused by $M$. genitalium can be long-term infertility, serological studies represent the best choice for addressing the issue whether this organism is a cause of TFI and can also be useful in determining recent or long-term infections (i.e., by comparing $\operatorname{IgM}$ and $\operatorname{IgG}$ antibodies) [102]. The crossreactions between M. genitalium and M. pneumoniae [172] have hampered the use of serology for diagnosis and epidemiological studies, but Wang et al. developed and evaluated a Triton X-114 extracted lipid-associated membrane protein (LAMP) assay without evident cross-reactivity [173]. Thus the LAMP-EIA method adapted by using two different strains of $M$. genitalium as antigen (in order to represent different antigenic variants of the pathogen) is currently used in most serological evaluations of tubal disorders and PID caused by this microorganism [101]. 
TABLE 1: General trends in C. trachomatis and genital mycoplasmas drug susceptibility.

\begin{tabular}{|c|c|c|c|c|}
\hline & C. trahomatis & M. hominis & U. urealyticum & M. genitalium \\
\hline Doxycycline & + & + & + & - \\
\hline Azithromycin & + & - & + & + \\
\hline Erythromycin & + & - & + & - \\
\hline Clindamycin & - & + & - & - \\
\hline Ciprofloxacin & + & + & + & - \\
\hline Levofloxacin & + & + & + & - \\
\hline Moxifloxacin & + & + & + & + \\
\hline
\end{tabular}

\section{Treatment and Antimicrobial Resistance}

Due to the absence of peptidoglycan layer in the cell wall of both Chlamydia and genital mycoplasmas, antimicrobial drugs that interfere with protein or nucleic acid synthesis (e.g., tetracyclines, macrolides, and quinolones) are recommended for the treatment. However, there are some specificities and general trends regarding susceptibility of each species (Table 1).

To date, C. trachomatis resistance has not been of great concern as majority of studies report excellent sensitivity of chlamydia in vitro and in vivo-even in countries with high antibiotic consumption rate $[147,174,175]$. However, clinical treatment failures have been reported and some of them linked to multidrug-resistant $C$. trachomatis strains which all demonstrate heterotypic resistance, which is a form of phenotypic resistance where a small proportion of an infecting microbial species is capable of expressing resistance [176-178]. Some researchers associate this phenomenon with chlamydial aberrancy, concluding that such phenotypic antibiotic resistance may be a possible adaptive behaviour of $C$. trachomatis under antibiotic stress rather than stable genetic resistance mechanism [179].

Although macrolides are considered as drugs of choice for treating mycoplasmal infections, caution is necessary since $M$. hominis shows intrinsic resistance to the $\mathrm{C} 14$ and C15 macrolides (erythromycin and azithromycin) [180]. On the other hand, Ureaplasma spp. is naturally resistant to lincosamides (e.g., clindamycin) [181]. Acquired resistance to macrolides of these species is associated with mutations in the $23 \mathrm{~S}$ rRNA gene $[182,183]$, whilst resistance to tetracyclines is related to the presence of the mobile tet $(M)$ genetic element $[184,185]$. Fluoroquinolones (particularly fourth-generation moxifloxacin) remain very effective against genital mycoplasmas, but resistance patterns show an increasing tendency and they are restricted to nonpregnant patients [186].

The rate of bacteriologic failure after treatment of $M$. genitalium with doxycycline is high and could lead to the development of chronic illness; hence this antibiotic is not recommended $[187,188]$. Both the single dose of $1 \mathrm{~g}$ and the extended treatment with $1.5 \mathrm{~g}$ azithromycin are efficient and they do not significantly differ, but, due to the increased selection of resistant clones, extended treatment with this drug is recommended [189]. However, as macrolide resistance is on a steep rise [190] and ciprofloxacin and levofloxacin do not show adequate efficiency [191], moxifloxacin is currently recommended as a drug of choice in cases of azithromycinresistant M. genitalium $[188,191]$. However, authors from Australia and Japan reported cases of clinical and microbiological moxifloxacin treatment failure in infections caused by this microorganism $[192,193]$. In the foresight, sitafloxacin could be a promising agent for M. genitalium infections [194] .

\section{Public Health Dimension and Conclusion}

Chlamydial and genital mycoplasma infections are the most important preventable causes of female infertility and adverse pregnancy outcomes. When they ascend, both of the infections can result in PID-a leading cause of TFI and EP. Screening could improve outcomes of infections by identifying and treating them before progressing to PID (direct effect) or by reducing their transmission (indirect effect) [195]. An improved understanding of the natural history of C. trachomatis and genital mycoplasma infections is essential to boost the control efforts [51,196]. Natural history studies would ideally help to better elucidate the incidence and timing of PID and tubal damage, resulting in long-term sequelae after untreated infections [197]. Such assessments would have to be done in diverse populations, including women with asymptomatic prevalent infection without the indication for testing, apart from screening. Also, further research is required to understand the dynamics of $C$. trachomatis and mycoplasma coinfections.

A critical component of research addressing natural history and the impact of chlamydia and mycoplasma screening is our aptitude to accurately measure the sequelae of these infections. We desperately need better, noninvasive tools for measuring the impact on human reproductive health. Diagnosis of acute PID is extremely subjective, insensitive, and nonspecific [198]. Infertility has multiple possible causes and may not be recognized for years after a chlamydial or mycoplasmal infection has resulted in a tubal damage, as the affected woman may not have tried to become pregnant. Thus it is essential to have tools to more accurately assess the sequelae observed as end-products (namely, PID, EP, and infertility) and also to noninvasively detect the prevailing pathophysiologic processes that forecast those sequelae [199]. The issue of morbidity and possible influence of those microorganisms on male fertility is still not completely clear; hence more research is needed in that direction to establish effective prevention programs. 
Vaccination could be considerably more effective than other biomedical interventions in controlling epidemics of $C$. trachomatis and genital mycoplasma infections. Administrating a protective vaccine to adolescents before their first sexual experience could induce a significant reduction in prevalence, which could not be achieved by screening teenagers (even with the full coverage) [200]. Unfortunately, no fully or partially protective vaccines are available despite prior attempts to develop one in case of C. trachomatis [201]. The immunological features of the genital system and the tropism of Chlamydia for mucosal epithelial cells underline the necessity of inducing both mucosal and systemic protective responses in an ideal vaccine [202]. The difficulty also arises because the male reproductive tract is an immune-privileged site that can be disrupted, possibly affecting spermatogenesis if ill-suited inflammatory responses are provoked [4]. Therefore for a better understanding of the immunologic, host, and organism factors that have a role in pathogenesis and the development of sequelae, a pursuit for relevant clinical markers and a viable vaccine could ultimately help guide targeted screening and control efforts of these important pathogens.

\section{Conflict of Interests}

The authors declare that there is no conflict of interests regarding the publication of this paper.

\section{References}

[1] Department of Reproductive Health and Research World Health Organization, Global Strategy for the Prevention and Control of Sexually Transmitted Infections: 2006-2015, WHO Press, Geneva, Switzerland, 2007.

[2] A. Gewirtzman, L. Bobrick, K. Conner, and S. K. Tyring, "Epidemiology of sexually transmitted infections," in Sexually Transmitted Infections and Sexually Transmitted Diseases, G. Gorss and S. K. Tyring, Eds., Springer, New York, NY, USA, 2011.

[3] O. Yeganeh, M. Jeddi-Tehrani, F. Yaghmaie et al., "A survey on the prevalence of Chlamydia trachomatis and Mycoplasma genitalium infections in symptomatic and asymptomatic men referring to urology clinic of Labbafinejad Hospital, Tehran, Iran," Iranian Red Crescent Medical Journal, vol. 15, no. 4, pp. 340-344, 2013.

[4] K. A. Cunningham and K. W. Beagley, "Male genital tract chlamydial infection: implications for pathology and infertility," Biology of Reproduction, vol. 79, no. 2, pp. 180-189, 2008.

[5] I. Simms, K. Eastick, H. Mallinson et al., "Associations between Mycoplasma genitalium, Chlamydia trachomatis, and pelvic inflammatory disease," Sexually Transmitted Infections, vol. 79, no. 2, pp. 154-156, 2003.

[6] N. Miron, D. Socolov, M. Mareș et al., "Bacteriological agents which play a role in the development of infertility," Acta Microbiologica et Immunologica Hungarica, vol. 60, no. 1, pp. 41-53, 2013.

[7] R. S. Stephens, S. Kalman, C. Lammel et al., "Genome sequence of an obligate intracellular pathogen of humans: Chlamydia trachomatis," Science, vol. 282, no. 5389, pp. 754-759, 1998.
[8] J. H. Carlson, W. M. Whitmire, D. D. Crane et al., "The Chlam$y$ dia trachomatis plasmid is a transcriptional regulator of chromosomal genes and a virulence factor," Infection and Immunity, vol. 76, no. 6, pp. 2273-2283, 2008.

[9] M. Comanducci, R. Cevenini, A. Moroni et al., "Expression of a plasmid gene of Chlamydia trachomatis encoding a novel 28 $\mathrm{kDa}$ antigen," Journal of General Microbiology, vol. 139, no. 5, pp. 1083-1092, 1993.

[10] T. Ripa and P. A. Nilsson, "A Chlamydia trachomatis strain with a 377-bp deletion in the cryptic plasmid causing false-negative nucleic acid amplification tests," Sexually Transmitted Diseases, vol. 34, no. 5, pp. 255-256, 2007.

[11] J. W. Moulder, "Interaction of chlamydiae and host cells in vitro," Microbiological Reviews, vol. 55, no. 1, pp. 143-190, 1991.

[12] P. M. Bavoil, R.-C. Hsia, and D. M. Ojcius, "Closing in on Chlamydia and its intracellular bag of tricks," Microbiology, vol. 146, part 11, pp. 2723-2731, 2000.

[13] P. B. Wyrick, "Chlamydia trachomatis persistence in vitro: an overview," The Journal of Infectious Diseases, vol. 201, supplement 2, pp. S88-S95, 2010.

[14] J. Kintner, D. Lajoie, J. Hall, J. Whittimore, and R. V. Schoborg, "Commonly prescribed $\beta$-lactam antibiotics induce C. trachomatis persistence/stress in culture at physiologically relevant concentrations," Frontiers in Cellular and Infection Microbiology, vol. 4, article 44, 2014.

[15] M. Malhotra, S. Sood, A. Mukherjee, S. Muralidhar, and M. Bala, "Genital Chlamydia trachomatis: an update," Indian Journal of Medical Research, vol. 138, pp. 303-316, 2013.

[16] H. Abdelsamed, J. Peters, and G. I. Byrne, "Genetic variation in Chlamydia trachomatis and their hosts: Impact on disease severity and tissue tropism," Future Microbiology, vol. 8, no. 9, pp. 1129-1146, 2013.

[17] G. I. Byrne, "Chlamydia trachomatis strains and virulence: rethinking links to infection prevalence and disease severity," Journal of Infectious Diseases, vol. 201, no. 2, pp. S126-S133, 2010.

[18] A. H. Kinnunen, H.-M. Surcel, M. Lehtinen et al., "HLA DQ alleles and interleukin-10 polymorphism associated with Chlamydia trachomatis-related tubal factor infertility: a casecontrol study," Human Reproduction, vol. 17, no. 8, pp. 20732078, 2002.

[19] K. B. Waites and D. Taylor-Robinson, "Mycoplasma and ureaplasma," in Manual of Clinical Microbiology, J. Versalovic, K. Carroll, G. Funke, J. Jorgensen, M. Landry, and D. W. Warnock, Eds., ASM Press, Washington, DC, USA, 10th edition, 2011.

[20] C. Citti and A. Blanchard, "Mycoplasmas and their host: emerging and re-emerging minimal pathogens," Trends in Microbiology, vol. 21, no. 4, pp. 196-203, 2013.

[21] A. Uusküla and P. K. Kohl, "Genital mycoplasmas, including Mycoplasma genitalium, as sexually transmitted agents," International Journal of STD and AIDS, vol. 13, no. 2, pp. 79-85, 2002.

[22] C. M. Fraser, J. D. Gocayne, O. White et al., "The minimal gene complement of Mycoplasma genitalium," Science, vol. 270, no. 5235, pp. 397-403, 1995.

[23] K. B. Waites, B. Katz, and R. L. Schelonka, "Mycoplasmas and ureaplasmas as neonatal pathogens," Clinical Microbiology Reviews, vol. 18, no. 4, pp. 757-789, 2005.

[24] B. Henrich, R.-C. Feldmann, and U. Hadding, "Cytoadhesins of Mycoplasma hominis," Infection and Immunity, vol. 61, no. 7, pp. 2945-2951, 1993. 
[25] P. C. Hu, U. Schaper, A. M. Collier et al., "A Mycoplasma genitalium protein resembling the Mycoplasma pneumoniae attachment protein," Infection and Immunity, vol. 55, no. 5, pp. 11261131, 1987.

[26] C. Citti, L.-X. Nouvel, and E. Baranowski, "Phase and antigenic variation in mycoplasmas," Future Microbiology, vol. 5, no. 7, pp. 1073-1085, 2010.

[27] S. N. Peterson, C. C. Bailey, J. S. Jensen et al., "Characterization of repetitive DNA in the Mycoplasma genitalium genome: possible role in the generation of antigenic variation," Proceedings of the National Academy of Sciences of the United States of America, vol. 92, no. 25, pp. 11829-11833, 1995.

[28] L. Li, M. Krishnan, J. B. Baseman, and T. R. Kannan, "Molecular cloning, expression, and characterization of a $\mathrm{Ca}^{2+}$-dependent, membrane-associated nuclease of Mycoplasma genitalium," Journal of Bacteriology, vol. 192, no. 19, pp. 4876-4884, 2010.

[29] S. L. Swanberg, G. K. Masover, and L. Hayflick, "Some characteristics of Ureaplasma urealyticum. Urease activity in a simple buffer: effect of metal ions and sulphydryl inhibitors," Journal of General Microbiology, vol. 108, no. 2, pp. 221-225, 1978.

[30] R. K. Spooner, W. C. Russell, and D. Thirkell, "Characterization of the immunoglobulin A protease of Ureaplasma urealyticum," Infection and Immunity, vol. 60, no. 6, pp. 2544-2546, 1992.

[31] S. Rottem, "Interaction of mycoplasmas with host cells," Physiological Reviews, vol. 83, no. 2, pp. 417-432, 2003.

[32] J. B. Baseman and J. G. Tully, "Mycoplasmas: sophisticated, reemerging, and burdened by their notoriety," Emerging Infectious Diseases, vol. 3, no. 1, pp. 21-32, 1997.

[33] S. F. Dallo and J. B. Baseman, "Intracellular DNA replication and long-term survival of pathogenic mycoplasmas," Microbial Pathogenesis, vol. 29, no. 5, pp. 301-309, 2000.

[34] V. Kucinskiene, I. Sutaite, S. Valiukeviciene, Z. Milasauskiene, and M. Domeika, "Prevalence and risk factors of genital Chlamydia trachomatis infection," Medicina, vol. 42, no. 11, pp. 885-894, 2006.

[35] Division of STD Prevention Centers for Disease Control and Prevention, National Center for HIV/AIDS, Viral Hepatitis, STD, and TB Prevention, "Sexually Transmitted Disease Surveillance 2012," http://www.cdc.gov/std/stats12/surv2012 .pdf.

[36] E. Eggleston, S. M. Rogers, C. F. Turner et al., "Chlamydia trachomatis infection among 15-to 35-year-olds in Baltimore, MD," Sexually Transmitted Diseases, vol. 38, no. 8, pp. 743-749, 2011.

[37] V. Goulet, B. De Barbeyrac, S. Raherison, M. Prudhomme, C. Semaille, and J. Warszawski, "Prevalence of Chlamydia trachomatis: results from the first national population-based survey in France," Sexually Transmitted Infections, vol. 86, no. 4, pp. 263-270, 2010.

[38] I. Božičević, I. Grgić, S. Židovec-Lepej et al., "Urine-based testing for Chlamydia trachomatis among young adults in a population-based survey in Croatia: feasibility and prevalence," BMC Public Health, vol. 11, article 230, 2011.

[39] S. L. Sternak, V. Kružić, T. Vilibić-Čavlek, and V. Skerk, “Chlamydia trachomatis infection in Croatian symptomatic and asymptomatic men [1]," Journal of Men's Health and Gender, vol. 3, no. 1, pp. 80-81, 2006.

[40] V. Škerk, V. Čajić, L. Markovinović et al., "Etiology of chronic prostatitis syndrome in patients treated at the university hospital for infectious diseases "Dr. Fran Mihaljević" from 2003 to 2005," Collegium Antropologicum, vol. 30, supplement 2, pp. 145-149, 2006.
[41] M. Pasini, V. Kotarski, V. Škerk et al., "The significance of Chlamydia trachomatis in prostatitis syndrome," Journal of Chemotherapy, vol. 26, no. 6, pp. 382-384, 2014.

[42] G. M. Daley, D. B. Russell, S. N. Tabrizi, and J. McBride, "Mycoplasma genitalium: a review," International Journal of STD \& AIDS, vol. 25, no. 7, pp. 475-487, 2014.

[43] L. Falk, H. Fredlund, and J. S. Jensen, "Symptomatic urethritis is more prevalent in men infected with Mycoplasma genitalium than with Chlamydia trachomatis," Sexually Transmitted Infections, vol. 80, no. 4, pp. 289-293, 2004.

[44] S. Sethi, G. Singh, P. Samanta, and M. Sharma, "Mycoplasma genitalium: an emerging sexually transmitted pathogen," Indian Journal of Medical Research, vol. 136, no. 6, pp. 942-955, 2012.

[45] N. Ružman, M. Miškulin, S. Rudan, and Z. Bošnjak, “The prevalence and the risk factors of the cervical colonization by the genital mycoplasmas among pregnant women from Eastern Croatia," Collegium Antropologicum, vol. 37, no. 1, pp. 135-140, 2013.

[46] B. Hunjak, I. Sabol, G. Vojnović et al., "Ureaplasma urealyticum and Ureaplasma parvum in women of reproductive age," Archives of Gynecology and Obstetrics, vol. 289, no. 2, pp. 407412, 2014

[47] V. Plečko, L. Žele Starčević, V. Tripković, V. Rezo Vranješ, and M. Skerlev, "Mycoplasma genitalium: clinical significance and diagnosis," Acta Dermatovenerologica Croatica, vol. 21, no. 4, pp. 236-240, 2013.

[48] M. Berntson and P. Tunbäck, "Clinical and microscopic signs of cervicitis and urethritis: correlation with Chlamydia trachomatis infection in female STI patients," Acta DermatoVenereologica, vol. 93, no. 2, pp. 230-233, 2013.

[49] J. Paavonen and W. Eggert-Kruse, "Chlamydia trachomatis: impact on human reproduction," Human Reproduction Update, vol. 5, no. 5, pp. 433-447, 1999.

[50] M. J. W. van de Laar and S. A. Morré, “Chlamydia: a major challenge for public health," Euro Surveillance, vol. 12, no. 10, pp. E1E2, 2007.

[51] C. L. Haggerty, S. L. Gottlieb, B. D. Taylor, N. Low, F. Xu, and R. B. Ness, "Risk of sequelae after Chlamydia trachomatis genital infection in women," The Journal of Infectious Diseases, vol. 201, supplement 2, pp. S134-S155, 2010.

[52] S. A. Herzog, C. L. Althaus, J. C. M. Heijne et al., "Timing of progression from Chlamydia trachomatis infection to pelvic inflammatory disease: a mathematical modelling study," $B M C$ Infectious Diseases, vol. 12, article 187, 2012.

[53] M. J. Price, A. E. Ades, D. de Angelis et al., "Risk of pelvic inflammatory disease following Chlamydia trachomatis infection: analysis of prospective studies with a multistate model," American Journal of Epidemiology, vol. 178, no. 3, pp. 484-492, 2013.

[54] C. Schindlbeck, D. Dziura, and I. Mylonas, "Diagnosis of pelvic inflammatory disease (PID): intra-operative findings and comparison of vaginal and intra-abdominal cultures," Archives of Gynecology and Obstetrics, vol. 289, no. 6, pp. 1263-1269, 2014.

[55] L. V. Westrom, "Sexually transmitted diseases and infertility," Sexually Transmitted Diseases, vol. 21, supplement 2, pp. S32S37, 1994.

[56] K. Agholor, L. Omo-Aghoja, and F. Okonofua, "Association of anti-Chlamydia antibodies with ectopic pregnancy in Benin city, Nigeria: a case-control study," African Health Sciences, vol. 13, no. 2, pp. 430-440, 2013.

[57] T. Naderi, F. Kazerani, and A. Bahrampoor, "Comparison of Chlamydia infection prevalence between patients with and 
without ectopic pregnancy using the PCR method," Ginekologia Polska, vol. 83, no. 11, pp. 819-821, 2012.

[58] H. C. Wiesenfeld, S. L. Hillier, L. A. Meyn, A. J. Amortegui, and R. L. Sweet, "Subclinical pelvic inflammatory disease and infertility," Obstetrics and Gynecology, vol. 120, no. 1, pp. 37-43, 2012.

[59] J. Debattista, C. M. Gazzard, R. N. Wood et al., "Interaction of microbiology and pathology in women undergoing investigations for infertility," Infectious Disease in Obstetrics and Gynecology, vol. 12, no. 3-4, pp. 135-145, 2004.

[60] J. Mania-Pramanik, S. Kerkar, S. Sonawane, P. Mehta, and V. Salvi, "Current Chlamydia trachomatis infection, a major cause of infertility," Journal of Reproduction and Infertility, vol. 13, no. 4, pp. 204-210, 2012.

[61] G. I. J. G. Rours, R. R. de Krijger, A. Ott et al., "Chlamydia trachomatis and placental inflammation in early preterm delivery," European Journal of Epidemiology, vol. 26, no. 5, pp. 421-428, 2011.

[62] S. Djukić, M. Nedeljković, M. Pervulov, A. Ljubić, N. Radunović, and B. Lazarević, "Intra-amniotic Chlamydia trachomatis infection," Gynecologic and Obstetric Investigation, vol. 42, no. 2, pp. 109-112, 1996.

[63] M. J. P. M. de Attayde Silva, G. L. Dantas Florêncio, J. R. Erbolato Gabiatti, R. L. do Amaral, J. E. Júnior, and A. K. da Silveira Gonçalves, "Perinatal morbidity and mortality associated with chlamydial infection: a meta-analysis study," Brazilian Journal of Infectious Diseases, vol. 15, no. 6, pp. 533-539, 2011.

[64] G. G. G. Donders, P. Moerman, G. H. de Wet, P. Hooft, and P. Goubau, "The association between Chlamydia cervicitis, chorioamnionitis and neonatal complications," Archives of Gynecology and Obstetrics, vol. 249, no. 2, pp. 79-85, 1991.

[65] M. Gencay, M. Koskiniemi, P. Saikku et al., "Chlamydia trachomatis seropositivity during pregnancy is associated with perinatal complications," Clinical Infectious Diseases, vol. 21, no. 2, pp. 424-426, 1995.

[66] M. Hernandez-Trejo, N. E. Herrera-Gonzalez, M. R. EscobedoGuerra et al., "Reporting detection of Chlamydia trachomatis DNA in tissues of neonatal death cases," Jornal de Pediatria, vol. 90, no. 2, pp. 182-189, 2014.

[67] M. M. Blas, F. A. Canchihuaman, I. E. Alva, and S. E. Hawes, "Pregnancy outcomes in women infected with Chlamydia trachomatis: a population-based cohort study in Washington State," Sexually Transmitted Infections, vol. 83, no. 4, pp. 314-318, 2007.

[68] H. Shariat, M. Young, and M. Abedin, "An interesting case presentation: a possible new route for perinatal acquisition of Chlamydia," Journal of Perinatology, vol. 12, no. 3, pp. 300-302, 1992.

[69] G. I. J. G. Rours, R. R. de Krijger, A. Ott et al., "Chlamydia trachomatis and placental inflammation in early preterm delivery," European Journal of Epidemiology, vol. 26, no. 5, pp. 421-428, 2011.

[70] M. Lehtinen, K. A. Ault, E. Lyytikainen et al., "Chlamydia trachomatis infection and risk of cervical intraepithelial neoplasia," Sexually Transmitted Infections, vol. 87, no. 5, pp. 372-376, 2011.

[71] J. Silva, F. Cerqueira, and R. Medeiros, "Chlamydia trachomatis infection: implications for HPV status and cervical cancer," Archives of Gynecology and Obstetrics, vol. 289, no. 4, pp. 715723, 2014.

[72] L. A. Dahlström, K. Andersson, T. Luostarinen et al., "Prospective seroepidemiologic study of human papillomavirus and other risk factors in cervical cancer," Cancer Epidemiology, Biomarkers \& Prevention, vol. 20, no. 12, pp. 2541-2550, 2011.

[73] K. E. Jensen, L. T. Thomsen, S. Schmiedel et al., "Chlamydia trachomatis and risk of cervical intraepithelial neoplasia grade 3 or worse in women with persistent human papillomavirus infection: a cohort study," Sexually Transmitted Infections, vol. 90, no. 7, pp. 550-555, 2014.

[74] C. Chumduri, R. K. Gurumurthy, P. K. Zadora, Y. Mi, and T. F. Meyer, "Chlamydia infection promotes host DNA damage and proliferation but impairs the DNA damage response," Cell Host \& Microbe, vol. 13, no. 6, pp. 746-758, 2013.

[75] N. Tungsrithong, C. Kasinpila, C. Maneenin et al., "Lack of significant effects of Chlamydia trachomatis infection on cervical cancer risk in a nested case-control study in North-East Thailand," Asian Pacific Journal of Cancer Prevention, vol. 15, no. 3, pp. 1497-1500, 2014.

[76] P. A. Mardh, L. Westrom, C. von Mecklenburg, and E. Hammar, "Studies on ciliated epithelia of the human genital tract. I. Swelling of the cilia of Fallopian tube epithelium in organ cultures infected with Mycoplasma hominis," The British Journal of Venereal Diseases, vol. 52, no. 1, pp. 52-57, 1976.

[77] K. Waites and D. Talkington, "New developments in human diseases due to mycoplasmas," in Mycoplasmas: Pathogenesis, Molecular Biology, and Emerging Strategies for Control, A. Blanchard and G. Browning, Eds., Horizon Scientific Press, Norwich, UK, 2005.

[78] A. Baczynska, H. F. Svenstrup, J. Fedder, S. Birkelund, and G. Christiansen, "The use of enzyme-linked immunosorbent assay for detection of Mycoplasma hominis antibodies in infertile women serum samples," Human Reproduction, vol. 20, no. 5, pp. 1277-1285, 2005.

[79] P. Tyagi, "Mycoplasmal antibodies as determined with an enzyme-linked immunosorbent assay, in tubal factor infertility.", Indian Journal of Medical Sciences, vol. 53, no. 11, pp. 481485, 1999.

[80] A. Gupta, A. Gupta, S. Gupta, A. Mittal, P. Chandra, and A. K. Gill, "Correlation of mycoplasma with unexplained infertility," Archives of Gynecology and Obstetrics, vol. 280, no. 6, pp. 981985, 2009.

[81] M. Mareş, D. Socolov, B. Doroftei, A. Botezatu, and C. D. Goia, "The prevalence of some bacterial markers in female patients undergoing an initial infertility evaluation in North-East Romania," Roumanian Archives of Microbiology and Immunology, vol. 68, no. 3, pp. 171-174, 2009.

[82] I. Günyeli, F. Abike, I. Dünder et al., “Chlamydia, Mycoplasma and Ureaplasma infections in infertile couples and effects of these infections on fertility," Archives of Gynecology and Obstetrics, vol. 283, no. 2, pp. 379-385, 2011.

[83] R. B. Kundsin, "Mycoplasmas in genitourinary tract infection and reproductive failure," in Progress in Gynecology, S. H. Sturgis and M. L. Taymor, Eds., Grune \& Stratton, New York, NY, USA, 1970.

[84] H. Gnarpe and J. Friberg, “T mycoplasmas as a possible cause for reproductive failure," Nature, vol. 242, no. 5393, pp. 120-121, 1973.

[85] V. Fenkci, M. Yilmazer, and O. C. Aktepe, "Have Ureaplasma urealyticum and Mycoplasma hominis infections any significant effect on female fertility?" Infezioni in Medicina, vol. 10, no. 4, pp. 220-223, 2002.

[86] P. Andreeva and A. Dimitrov, "The microorganisms associated with bacterial vaginosis as a cause of tubal sterility," Akusherstvo i Ginekologiia, vol. 41, no. 4, pp. 35-39, 2002. 
[87] R. M. Viscardi, “Ureaplasma species: role in neonatal morbidities and outcomes," Archives of Disease in Childhood: Fetal and Neonatal Edition, vol. 99, no. 1, pp. F87-F92, 2014.

[88] M. Kacerovský, M. Pavlovský, and J. Tosner, "Preterm premature rupture of the membranes and genital mycoplasmas," Acta Medica, vol. 52, no. 3, pp. 117-120, 2009.

[89] B. Larsen and J. Hwang, "Mycoplasma, Ureaplasma, and adverse pregnancy outcomes: a fresh look," Infectious Diseases in Obstetrics and Gynecology, vol. 2010, Article ID 521921, 7 pages, 2010.

[90] M. Breugelmans, E. Vancutsem, A. Naessens, M. Laubach, and W. Foulon, "Association of abnormal vaginal flora and Ureaplasma species as risk factors for preterm birth: a cohort study," Acta Obstetricia et Gynecologica Scandinavica, vol. 89, no. 2, pp. 256-260, 2010.

[91] M. Kacerovský and L. Boudyš, "Preterm premature rupture of membranes and Ureaplasma urealyticum," Ceska Gynekologie, vol. 73, no. 3, pp. 154-159, 2008.

[92] F. Namba, T. Hasegawa, M. Nakayama et al., "Placental features of chorioamnionitis colonized with Ureaplasma species in preterm delivery," Pediatric Research, vol. 67, no. 2, pp. 166-172, 2010.

[93] D. C. Kasper, T. P. Mechtler, G. H. Reischer et al., "The bacterial load of Ureaplasma parvum in amniotic fluid is correlated with an increased intrauterine inflammatory response," Diagnostic Microbiology and Infectious Disease, vol. 67, no. 2, pp. 117-121, 2010.

[94] S. Kataoka, T. Yamada, K. Chou et al., "Association between preterm birth and vaginal colonization by mycoplasmas in early pregnancy," Journal of Clinical Microbiology, vol. 44, no. 1, pp. 51-55, 2006.

[95] D. Taylor-Robinson, P. M. Furr, J. G. Tully, M. F. Barile, and B. R. Møller, "Animal models of Mycoplasma genitalium urogenital infection," Israel Journal of Medical Sciences, vol. 23, no. 6, pp. 561-564, 1987.

[96] C. Bjartling, S. Osser, and K. Persson, "The association between Mycoplasma genitalium and pelvic inflammatory disease after termination of pregnancy," BJOG: An International Journal of Obstetrics \& Gynaecology, vol. 117, no. 3, pp. 361-364, 2010.

[97] C. Bjartling, S. Osser, and K. Persson, "Mycoplasma genitalium in cervicitis and pelvic inflammatory disease among women at a gynecologic outpatient service," American Journal of Obstetrics and Gynecology, vol. 206, no. 6, pp. 476.el-476.e8, 2012.

[98] C. L. Haggerty, P. A. Totten, S. G. Astete et al., "Failure of cefoxitin and doxycycline to eradicate endometrial Mycoplasma genitalium and the consequence for clinical cure of pelvic inflammatory disease," Sexually Transmitted Infections, vol. 84, no. 5, pp. 338-342, 2008.

[99] C. L. Haggerty and B. D. Taylor, "Mycoplasma genitalium: an emerging cause of pelvic inflammatory disease," Infectious Diseases in Obstetrics and Gynecology, vol. 2011, Article ID 959816, 9 pages, 2011.

[100] C. R. Cohen, M. Nosek, A. Meier et al., "Mycoplasma genitalium infection and persistence in a cohort of female sex workers in Nairobi, Kenya," Sexually Transmitted Diseases, vol. 34, no. 5, pp. 274-279, 2007.

[101] M. Jurstrand, J. S. Jensen, A. Magnuson, F. Kamwendo, and H. Fredlund, "A serological study of the role of Mycoplasma genitalium in pelvic inflammatory disease and ectopic pregnancy," Sexually Transmitted Infections, vol. 83, no. 4, pp. 319-323, 2007.

[102] C. L. McGowin and C. Anderson-Smits, "Mycoplasma genitalium: an emerging cause of sexually transmitted disease in women," PLoS Pathogens, vol. 7, no. 5, Article ID e1001324, 2011.
[103] P. Oakeshott, P. Hay, D. Taylor-Robinson et al., "Prevalence of Mycoplasma genitalium in early pregnancy and relationship between its presence and pregnancy outcome," BJOG: An International Journal of Obstetrics \& Gynaecology, vol. 111, no. 12, pp. 1464-1467, 2004.

[104] R. Edwards, R. Ferguson, L. Reyes, M. Brown, D. Theriaque, and P. Duff, "Assessing the relationship between preterm delivery and various microorganisms recovered from the lower genital tract," Journal of Maternal-Fetal and Neonatal Medicine, vol. 19, no. 6, pp. 357-363, 2006.

[105] J. Hitti, P. Garcia, P. Totten, K. Paul, S. Astete, and K. K. Holmes, "Correlates of cervical Mycoplasma genitalium and risk of preterm birth among Peruvian women," Sexually Transmitted Diseases, vol. 37, no. 2, pp. 81-85, 2010.

[106] A.-C. Labbé, E. Frost, S. Deslandes, A. P. Mendonça, A. C. Alves, and J. Pépin, "Mycoplasma genitalium is not associated with adverse outcomes of pregnancy in Guinea-Bissau," Sexually Transmitted Infections, vol. 78, no. 4, pp. 289-291, 2002.

[107] V. L. Short, J. S. Jensen, D. B. Nelson, P. J. Murray, R. B. Ness, and C. L. Haggerty, "Mycoplasma genitalium among young, urban pregnant women," Infectious Diseases in Obstetrics and Gynecology, vol. 2010, Article ID 984760, 8 pages, 2010.

[108] H. F. Clausen, J. Fedder, M. Drasbek et al., "Serological investigation of Mycoplasma genitalium in infertile women," Human Reproduction, vol. 16, no. 9, pp. 1866-1874, 2001.

[109] H. F. Svenstrup, J. Fedder, S. E. Kristoffersen, B. Trolle, S. Birkelund, and G. Christiansen, "Mycoplasma genitalium, Chlamydia trachomatis, and tubal factor infertility-a prospective study," Fertility and Sterility, vol. 90, no. 3, pp. 513-520, 2008.

[110] J. Grześko, M. Elias, B. Maczyńska, U. Kasprzykowska, M. Tłaczała, and M. Goluda, "Occurrence of Mycoplasma genitalium in fertile and infertile women," Fertility and Sterility, vol. 91, no. 6, pp. 2376-2380, 2009.

[111] A. Baczynska, P. Funch, J. Fedder, H. J. Knudsen, S. Birkelund, and G. Christiansen, "Morphology of human Fallopian tubes after infection with Mycoplasma genitalium and Mycoplasma hominis-in vitro organ culture study," Human Reproduction, vol. 22, no. 4, pp. 968-979, 2007.

[112] G. F. Gonzales, G. Muñoz, R. Sánchez et al., "Update on the impact of Chlamydia trachomatis infection on male fertility," Andrologia, vol. 36, no. 1, pp. 1-23, 2004.

[113] K. K. Holmes, H. H. Handsfield, S. P. Wang et al., "Etiology of nongonococcal urethritis," The New England Journal of Medicine, vol. 292, no. 23, pp. 1199-1205, 1975.

[114] M. D. Kiviat, N. B. Kiviat, and R. E. Berger, "Chlamydia trachomatis epididymitis diagnosed by fluorescent monoclonal antibody," Urology, vol. 30, no. 4, pp. 395-397, 1987.

[115] T. H. Trojian, T. S. Lishnak, and D. Heiman, "Epididymitis and orchitis: an overview," American Family Physician, vol. 79, no. 7, pp. 583-587, 2009.

[116] N. A. F. Walker and B. Challacombe, "Managing epididymoorchitis in general practice," The Practitioner, vol. 257, no. 1760, pp. 21-25, 2013.

[117] V. Škerk, S. L. Sternak, S. Roglić, and M. Lisić, "Diagnosis and treatment of chronic prostatitis caused by Chlamydia trachomatis," Journal of Chemotherapy, vol. 17, no. 5, pp. 570-571, 2005.

[118] V. Škerk, I. Krhen, V. Čajić et al., "The role of Chlamydia trachomatis in prostatitis syndrome-our experience in diagnosis and treatment," Acta Dermatovenerologica Croatica, vol. 15, no. 3, pp. 135-140, 2007. 
[119] Y. S. Choi, K. S. Kim, S. W. Choi et al., "Microbiological etiology of bacterial prostatitis in general hospital and primary care clinic in Korea," Prostate International, vol. 1, no. 3, pp. 133-138, 2013.

[120] S. Mazzoli, D. Bani, A. Salvi et al., "In vivo evidence of Chlamydia trachomatis miniature reticulary bodies (MRB) as persistence markers in patients with chronic chlamydial prostatitis," in Proceedings of the 4th European Society for Chlamydia Research Meeting, p. 40, 2000.

[121] M. A. González-Jiménez and C. A. Villanueva-Díaz, "Epididymal stereocilia in semen of infertile men: evidence of chronic epididymitis?" Andrologia, vol. 38, no. 1, pp. 26-30, 2006.

[122] A. Eley, A. A. Pacey, M. Galdiero, and F. Galdiero, "Can Chlamydia trachomatis directly damage your sperm?" The Lancet Infectious Diseases, vol. 5, no. 1, pp. 53-57, 2005.

[123] A. Al-Moushaly, "Recent acquisitions in the medical treatment of infertility caused by Chlamydia Trachomatis," Journal of Medicine and Life, vol. 6, no. 2, pp. 168-170, 2013.

[124] Y.-S. Lee and K.-S. Lee, "Chlamydia and male lower urinary tract diseases," Korean Journal of Urology, vol. 54, no. 2, pp. 7377, 2013.

[125] J. Liu, Q. Wang, X. Ji et al., "Prevalence of Ureaplasma urealyticum, Mycoplasma hominis, Chlamydia trachomatis infections, and semen quality in infertile and fertile men in China," Urology, vol. 83, no. 4, pp. 795-799, 2014.

[126] S. Hosseinzadeh, I. A. Brewis, A. A. Pacey, H. D. M. Moore, and A. Eley, "Coincubation of human spermatozoa with Chlamydia trachomatis in vitro causes increased tyrosine phosphorylation of sperm proteins," Infection and Immunity, vol. 68, no. 9, pp. 4872-4876, 2000.

[127] S. Hosseinzadeh, I. A. Brewis, A. Eley, and A. A. Pacey, "Coincubation of human spermatozoa with Chlamydia trachomatis serovar E causes premature sperm death," Human Reproduction, vol. 16, no. 2, pp. 293-299, 2001.

[128] C. Keck, C. Gerber-Schäfer, A. Clad, C. Wilhelm, and M. Breckwoldt, "Seminal tract infections: impact on male fertility and treatment options," Human Reproduction Update, vol. 4, no. 6, pp. 891-903, 1998.

[129] Y. Wang, C.-L. Liang, J.-Q. Wu, C. Xu, S.-X. Qin, and E.-S. Gao, "Do Ureaplasma urealyticum infections in the genital tract affect semen quality?" Asian Journal of Andrology, vol. 8, no. 5, pp. 562-568, 2006.

[130] R. B. Kundsin, S. G. Driscoll, and P.-M. L. Ming, "Strain of mycoplasma associated with human reproductive failure," Science, vol. 157, no. 3796, pp. 1573-1574, 1967.

[131] J. Friberg and H. Gnarpe, "Mycoplasmas in semen from fertile and infertile men," Andrologia, vol. 6, no. 1, pp. 45-52, 1974.

[132] K. Purvis and E. Christiansen, "Infection in the male reproductive tract. Impact, diagnosis and treatment in relation to male infertility," International Journal of Andrology, vol. 16, no. 1, pp. 1-13, 1993.

[133] C. Xu, G. F. Sun, Y. F. Zhu, and Y. F. Wang, "The correlation of Ureaplasma urealyticum infection with infertility," Andrologia, vol. 29, no. 4, pp. 219-226, 1997.

[134] D. Sanocka-Maciejewska, M. Ciupińska, and M. Kurpisz, "Bacterial infection and semen quality," Journal of Reproductive Immunology, vol. 67, no. 1-2, pp. 51-56, 2005.

[135] J. S. Lee, K. T. Kim, H. S. Lee, K. M. Yang, J. T. Seo, and J. H. Choe, "Concordance of Ureaplasma urealyticum and mycoplasma hominis in infertile couples: impact on semen parameters," Urology, vol. 81, no. 6, pp. 1219-1224, 2013.
[136] X.-Y. Xia, L.-M. An, W.-W. Li et al., "Ureaplasma urealyticum infection affects sperm plasma membrane integrity in infertile men," Zhonghua Nan Ke Xue, vol. 17, no. 12, pp. 1069-1072, 2011.

[137] B. Pajović, N. Radojević, M. Vuković, and A. Stjepčević, "Semen analysis before and after antibiotic treatment of asymptomatic Chlamydia- and Ureaplasma-related pyospermia," Andrologia, vol. 45, no. 4, pp. 266-271, 2013.

[138] M. Salmeri, D. Valenti, S. la Vignera et al., "Prevalence of Ureaplasma urealyticum and Mycoplasma hominis infection in unselected infertile men," Journal of Chemotherapy, vol. 24, no. 2, pp. 81-86, 2012.

[139] R. Gdoura, W. Kchaou, C. Chaari et al., "Ureaplasma urealyticum, Ureaplasma parvum, Mycoplasma hominis and Mycoplasma genitalium infections and semen quality of infertile men," BMC Infectious Diseases, vol. 7, article 129, 2007.

[140] F. J. Díaz-García, A. P. Herrera-Mendoza, S. Giono-Cerezo, and F. M. Guerra-Infante, "Mycoplasma hominis attaches to and locates intracellularly in human spermatozoa," Human Reproduction, vol. 21, no. 6, pp. 1591-1598, 2006.

[141] H. F. Svenstrup, J. Fedder, J. Abraham-Peskir, S. Birkelund, and G. Christiansen, "Mycoplasma genitalium attaches to human spermatozoa," Human Reproduction, vol. 18, no. 10, pp. 21032109, 2003

[142] J. N. Krieger and D. E. Riley, "Chronic prostatitis: charlottesville to seattle," Journal of Urology, vol. 172, no. 6, part 2, pp. 25572560, 2004.

[143] N. A. Al-Sweih, A. H. Al-Fadli, A. E. Omu, and V. O. Rotimi, "Prevalence of Chlamydia trachomatis, Mycoplasma hominis, Mycoplasma genitalium, and Ureaplasma urealyticum infections and seminal quality in infertile and fertile men in Kuwait," Journal of Andrology, vol. 33, no. 6, pp. 1323-1329, 2012.

[144] W. E. Stamm, M. Tam, M. Koester, and L. Cles, "Detection of Chlamydia trachomatis inclusions in McCoy cell cultures with fluorescein-conjugated monoclonal antibodies," Journal of Clinical Microbiology, vol. 17, no. 4, pp. 666-668, 1983.

[145] C. M. Black, "Current methods of laboratory diagnosis of Chlamydia trachomatis infections," Clinical Microbiology Reviews, vol. 10, no. 1, pp. 160-184, 1997.

[146] A. Visser and A. Hoosen, "Diagnosis of Chlamydia trachomatis infection," in Chlamydia, M. Mares, Ed., InTech, 2012.

[147] R. J. Suchland, W. M. Geisler, and W. E. Stamm, "Methodologies and cell lines used for antimicrobial susceptibility testing of Chlamydia spp," Antimicrobial Agents and Chemotherapy, vol. 47, no. 2, pp. 636-642, 2003.

[148] S. L. Sternak and V. Škerk, "Determining antimicrobial resistance to Chlamydia trachomatis and applying present findings in daily practice," Medicinski Glasnik, vol. 7, no. 1, pp. 26-31, 2010.

[149] H. Zeighami, S. N. Peerayeh, and M. Safarlu, "Detection of Ureaplasma urealyticum in semen of infertile men by PCR," Pakistan Journal of Biological Sciences, vol. 10, no. 21, pp. 39603963, 2007.

[150] X. Cao, Z. Jiang, Y. Wang, R. Gong, and C. Zhang, "Two multiplex real-time TaqMan polymerase chain reaction systems for simultaneous detecting and serotyping of Ureaplasma parvum," Diagnostic Microbiology and Infectious Disease, vol. 59, no. 1, pp. 109-111, 2007.

[151] M. J. Redelinghuys, M. M. Ehlers, A. W. Dreyer, H. A. Lombaard, and M. M. Kock, "Comparison of the new Mycofast Revolution assay with a molecular assay for the detection of genital mycoplasmas from clinical specimens," BMC Infectious Diseases, vol. 13, no. 1, article 453, 2013. 
[152] J. S. Jensen, "Mycoplasma genitalium infections. Diagnosis clinical aspects, and pathogenesis," Danish Medical Journal, vol. 53, no. 1, pp. 1-27, 2006.

[153] H. Thejls, J. Gnarpe, H. Gnarpe et al., "Expanded gold standard in the diagnosis of Chlamydia trachomatis in a low prevalence population: diagnostic efficacy of tissue culture, direct immunofluorescence, enzyme immunoassay, PCR and serology," Genitourinary Medicine, vol. 70, no. 5, pp. 300-303, 1994.

[154] J. A. Kellogg, J. W. Seiple, and M. E. Hick, "Cross-reaction of clinical isolates of bacteria and yeasts with the Chlamydiazyme test for Chlamydial antigen, before and after use of a blocking reagent," American Journal of Clinical Pathology, vol. 97, no. 3, pp. 309-312, 1992.

[155] S. V. Jalgaonkar, A. A. Pathak, Y. S. Thakar, and M. M. Kher, "Enzyme immunoassay for rapid detection of Chlamydia trachomatis in urogenital infections," Indian Journal of Sexually Transmitted Diseases, vol. 11, no. 1, pp. 23-26, 1990.

[156] J. B. Mahony, K. E. Luinstra, J. W. Sellors, and M. A. Chernesky, "Comparison of plasmid- and chromosome-based polymerase chain reaction assays for detecting Chlamydia trachomatis nucleic acids," Journal of Clinical Microbiology, vol. 31, no. 7, pp. 1753-1758, 1993.

[157] J. K. Møller, L. N. Pedersen, and K. Persson, "Comparison of the Abbott RealTime CT new formulation assay with two other commercial assays for detection of wild-type and new variant strains of Chlamydia trachomatis," Journal of Clinical Microbiology, vol. 48, no. 2, pp. 440-443, 2010.

[158] M. Hartmann, "Genital mycoplasmas," Journal der Deutschen Dermatologischen Gesellschaft, vol. 7, no. 4, pp. 371-377, 2009.

[159] K. B. Waites, L. Xiao, V. Paralanov, R. M. Viscardi, and J. I. Glass, "Molecular methods for the detection of Mycoplasma and Ureaplasma infections in humans: a paper from the 2011 William Beaumont Hospital symposium on molecular pathology," Journal of Molecular Diagnostics, vol. 14, no. 5, pp. 437-450, 2012.

[160] M. A. Meseguer-Peinado, B. Acosta-Boga, L. Matas-Andreu, and G. Codina-Grau, "Microbiological diagnosis of Mycoplasma infections," Enfermedades Infecciosas y Microbiología Clínica, vol. 30, no. 8, pp. 500-504, 2012.

[161] Y. Kim, J. Kim, and K.-A. Lee, "Prevalence of sexually transmitted infections among healthy Korean women: implications of multiplex PCR pathogen detection on antibiotic therapy," Journal of Infection and Chemotherapy, vol. 20, no. 1, pp. 74-76, 2014.

[162] H.-S. Choe, D. S. Lee, S.-J. Lee et al., "Performance of Anyplex ${ }^{\text {TM }}$ II multiplex real-time PCR for the diagnosis of seven sexually transmitted infections: comparison with currently available methods," International Journal of Infectious Diseases, vol. 17, no. 12, pp. el134-e1140, 2013.

[163] M. L. McKechnie, F. Kong, and G. L. Gilbert, "Simultaneous direct identification of genital microorganisms in voided urine using multiplex PCR-based reverse line blot assays," Methods in Molecular Biology, vol. 943, pp. 229-245, 2013.

[164] M. Schmitt, C. Depuydt, M. Stalpaert, and M. Pawlita, "Beadbased multiplex sexually transmitted infection profiling," Journal of Infection, vol. 69, no. 2, pp. 123-133, 2014.

[165] A. Arsovic, A. Nikolov, P. Sazdanovic, S. Popovic, and D. Baskic, "Prevalence and diagnostic significance of specific IgA and antiheat shock protein 60 Chlamydia trachomatis antibodies in subfertile women," European Journal of Clinical Microbiology \& Infectious Diseases, vol. 33, no. 5, pp. 761-766, 2014.
[166] Z. Raoofi, M. Barchinegad, and L. Haghighi, "The value of negative Chlamydia trachomatis antibody in prediction of normal tubes in infertile women," Clinical and Experimental Obstetrics and Gynecology, vol. 40, no. 1, pp. 95-97, 2013.

[167] J. N. Arno, Y. Yuan, R. E. Cleary, and R. P. Morrison, "Serologic responses of infertile women to the $60-\mathrm{kd}$ chlamydial heat shock protein (hsp60)," Fertility and Sterility, vol. 64, no. 4, pp. 730-735, 1995.

[168] P. Claman, L. Honey, R. W. Peeling, P. Jessamine, and B. Toye, "The presence of serum antibody to the chlamydial heat shock protein (CHSP60) as a diagnostic test for tubal factor infertility," Fertility and Sterility, vol. 67, no. 3, pp. 501-504, 1997.

[169] C. J. Bax, P. J. Dörr, J. B. Trimbos et al., "Chlamydia trachomatis heat shock protein 60 (cHSP60) antibodies in women without and with tubal pathology using a new commercially available assay," Sexually Transmitted Infections, vol. 80, no. 5, pp. 415416, 2004.

[170] C. M. Gazzard, R. N. Wood, J. Debattista, J. A. Allan, J. M. Allan, and P. Timms, "Use of a commercial assay for detecting the 60 $\mathrm{kDa}$ chlamydial heat shock protein in a range of patient groups," Sexually Transmitted Diseases, vol. 33, no. 2, pp. 77-79, 2006.

[171] T. Collet, T. Macnaughton, T. Walsh, J. Debattista, and P. Timms, "Identification of novel markers for uncomplicated lower genital tract infections and upper genital tract pathology due to Chlamydia trachomatis," International Journal of Infectious Diseases, vol. 15, no. 4, pp. e257-e266, 2011.

[172] D. Taylor-Robinson, P. M. Furr, and J. G. Tully, "Serological cross-reactions between Mycoplasma genitalium and M. pneumoniae," The Lancet, vol. 1, no. 8323, p. 527, 1983.

[173] R. Y.-H. Wang, T. Grandinetti, J. W.-K. Shih et al., "Mycoplasma genitalium infection and host antibody immune response in patients infected by HIV, patients attending STD clinics and in healthy blood donors," FEMS Immunology and Medical Microbiology, vol. 19, no. 3, pp. 237-245, 1997.

[174] M. Donati, A. di Francesco, A. D’Antuono et al., "In vitro activities of several antimicrobial agents against recently isolated and genotyped Chlamydia trachomatis urogenital serovars D through K," Antimicrobial Agents and Chemotherapy, vol. 54, no. 12, pp. 5379-5380, 2010.

[175] S. Ljubin-Sternak, T. Mestrovic, T. Vilibic-Cavlek et al., "In vitro susceptibility of urogenital Chlamydia trachomatis strains in a country with high azithromycin consumption rate," Folia Microbiologica, vol. 58, no. 5, pp. 361-365, 2013.

[176] R. B. Jones, B. van der Pol, D. H. Martin, and M. K. Shepard, "Partial characterization of Chlamydia trachomatis isolates resistant to multiple antibiotics," The Journal of Infectious Diseases, vol. 162, no. 6, pp. 1309-1315, 1990.

[177] J. Somani, V. B. Bhullar, K. A. Workowski, C. E. Farshy, and C. M. Black, "Multiple drug-resistant Chlamydia trachomatis associated with clinical treatment failure," The Journal of Infectious Diseases, vol. 181, no. 4, pp. 1421-1427, 2000.

[178] A. R. Bhengraj, H. Vardhan, P. Srivastava, S. Salhan, and A. Mittal, "Decreased susceptibility to azithromycin and doxycycline in clinical isolates of Chlamydia trachomatis obtained from recurrently infected female patients in India," Chemotherapy, vol. 56, no. 5, pp. 371-377, 2010.

[179] K. M. Sandoz and D. D. Rockey, "Antibiotic resistance in Chlamydiae," Future Microbiology, vol. 5, no. 9, pp. 1427-1442, 2010.

[180] N. Kechagia, S. Bersimis, and S. Chatzipanagiotou, "Incidence and antimicrobial susceptibilities of genital mycoplasmas in 
outpatient women with clinical vaginitis in Athens, Greece," Journal of Antimicrobial Chemotherapy, vol. 62, no. 1, pp. 122125, 2008.

[181] C. M. Bébéar and C. Bébéar, "Antimycoplasmal agents," in Molecular Biology and Pathogenicity of Mycoplasmas, S. Razin and R. Herrmann, Eds., Kluwer Academic/Plenum, London, UK, 2002.

[182] M. Dongya, X. Wencheng, M. Xiaobo, and W. Lu, "Transition mutations in $23 \mathrm{~S}$ rRNA account for acquired resistance to macrolides in Ureaplasma urealyticum," Microbial Drug Resistance, vol. 14, no. 3, pp. 183-186, 2008.

[183] L. Xiao, D. M. Crabb, L. B. Duffy et al., "Mutations in ribosomal proteins and ribosomal RNA confer macrolide resistance in human Ureaplasma spp," International Journal of Antimicrobial Agents, vol. 37, no. 4, pp. 377-379, 2011.

[184] S. Dégrange, H. Renaudin, A. Charron, C. Bébéar, and C. M. Bébéar, "Tetracycline resistance in Ureaplasma spp. and Mycoplasma hominis: prevalence in Bordeaux, France, from 1999 to 2002 and description of two tet(M)-positive isolates of $M$. hominis susceptible to tetracyclines," Antimicrobial Agents and Chemotherapy, vol. 52, no. 2, pp. 742-744, 2008.

[185] B. B. A. Mardassi, N. Aissani, I. Moalla, D. Dhahri, A. Dridi, and B. Mlik, "Evidence for the predominance of a single tet $(\mathrm{M})$ gene sequence type in tetracycline-resistant Ureaplasma parvum and Mycoplasma hominis isolates from Tunisian patients," Journal of Medical Microbiology, vol. 61, no. 9, pp. 1254-1261, 2012.

[186] M. J. Redelinghuys, M. M. Ehlers, A. W. Dreyer, H. A. Lombaard, and M. M. Kock, "Antimicrobial susceptibility patterns of Ureaplasma species and Mycoplasma hominis in pregnant women," BMC Infectious Diseases, vol. 14, no. 1, article 171, 2014.

[187] L. A. Mena, T. F. Mroczkowski, M. Nsuami, and D. H. Martin, "A randomized comparison of azithromycin and doxycycline for the treatment of Mycoplasma genitalium-positive urethritis in men," Clinical Infectious Diseases, vol. 48, no. 12, pp. 1649-1654, 2009.

[188] D. Taylor-Robinson, "Diagnosis and antimicrobial treatment of Mycoplasma genitalium infection: sobering thoughts," Expert Review of Anti-Infective Therapy, vol. 12, no. 6, pp. 715-722, 2014.

[189] C. Anagrius, B. Loré, and J. S. Jensen, "Treatment of Mycoplasma genitalium. Observations from a Swedish STD Clinic," PLoS ONE, vol. 8, no. 4, Article ID e61481, 2013.

[190] M. J. Pond, A. V. Nori, A. A. Witney, R. C. Lopeman, P. D. Butcher, and S. T. Sadiq, "High prevalence of antibiotic-resistant Mycoplasma genitalium in nongonococcal urethritis: the need for routine testing and the inadequacy of current treatment options," Clinical Infectious Diseases, vol. 58, no. 5, pp. 631-637, 2014.

[191] R. Hamasuna, "Identification of treatment strategies for Mycoplasma genitalium-related urethritis in male patients by culturing and antimicrobial susceptibility testing," Journal of Infection and Chemotherapy, vol. 19, no. 1, pp. 1-11, 2013.

[192] D. L. Couldwell, K. A. Tagg, N. J. Jeoffreys, and G. L. Gilbert, "Failure of moxifloxacin treatment in Mycoplasma genitalium infections due to macrolide and fluoroquinolone resistance," International Journal of STD \& AIDS, vol. 24, no. 10, pp. 822828,2013

[193] M. Kikuchi, S. Ito, M. Yasuda et al., "Remarkable increase in fluoroquinolone-resistant Mycoplasma genitalium in Japan," Journal of Antimicrobial Chemotherapy, vol. 69, no. 9, pp. 2376-2382, 2014.

[194] T. Deguchi, M. Kikuchi, M. Yasuda, and S. Ito, "Sitafloxacin: antimicrobial activity against ciprofloxacin-selected laboratory mutants of Mycoplasma genitalium and inhibitory activity against its DNA gyrase and topoisomerase IV," Journal of Infection and Chemotherapy, 2014.

[195] S. A. Herzog, J. C. M. Heijne, P. Scott, C. L. Althaus, and N. Low, "Direct and indirect effects of screening for Chlamydia trachomatis on the prevention of pelvic inflammatory disease: a mathematical modeling study," Epidemiology, vol. 24, no. 6, pp. 854-862, 2013.

[196] C. Bjartling and K. Persson, "Chlamydiaand genital mycoplasma: epidemiology and risks," Lakartidningen, vol. 107, no. 6, pp. 341-345, 2010.

[197] S. L. Gottlieb, S. M. Berman, and N. Low, "Screening and treatment to prevent sequelae in women with Chlamydia trachomatis genital infection: how much do we know?" The Journal of Infectious Diseases, vol. 201, supplement 2, pp. S156-S167, 2010.

[198] I. Simms, F. Warburton, and L. Weström, "Diagnosis of pelvic inflammatory disease: time for a rethink," Sexually Transmitted Infections, vol. 79, no. 6, pp. 491-494, 2003.

[199] L. J. Jackson, P. Auguste, N. Low, and T. E. Roberts, "Valuing the health states associated with Chlamydia trachomatis infections and their sequelae: a systematic review of economic evaluations and primary studies," Value in Health, vol. 17, no. 1, pp. 116-130, 2014.

[200] W. M. Huston, M. Harvie, A. Mittal, P. Timms, and K. W. Beagley, "Vaccination to protect against infection of the female reproductive tract," Expert Review of Clinical Immunology, vol. 8, no. 1, pp. 81-94, 2012.

[201] D. C. W. Mabey, V. Hu, R. L. Bailey, M. J. Burton, and M. J. Holland, "Towards a safe and effective chlamydial vaccine: lessons from the eye," Vaccine, vol. 32, no. 14, pp. 1572-1578, 2014.

[202] S. Vasilevsky, G. Greub, D. Nardelli-Haefliger, and D. Baud, "Genital Chlamydia trachomatis: understanding the roles of innate and adaptive immunity in vaccine research," Clinical Microbiology Reviews, vol. 27, no. 2, pp. 346-370, 2014. 


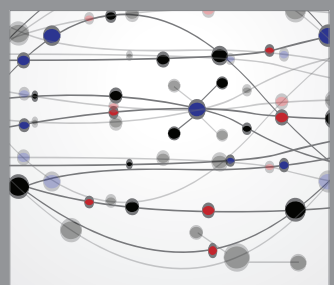

The Scientific World Journal
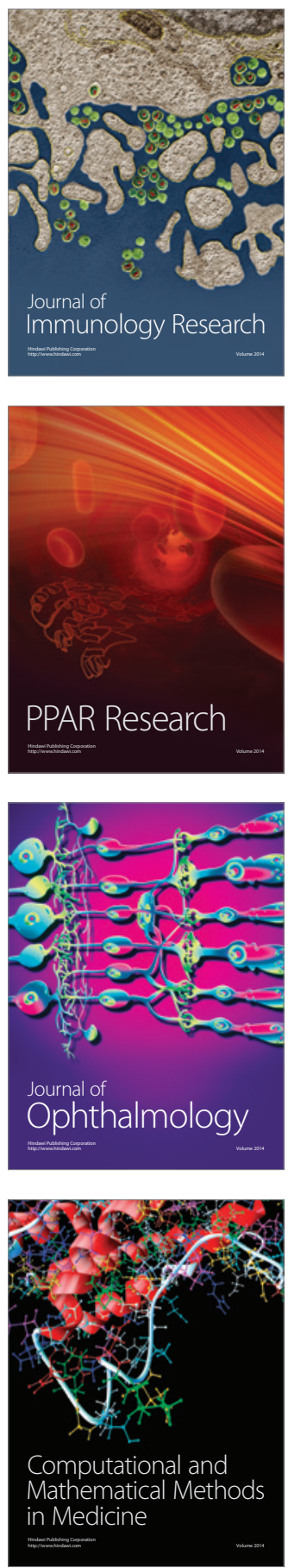

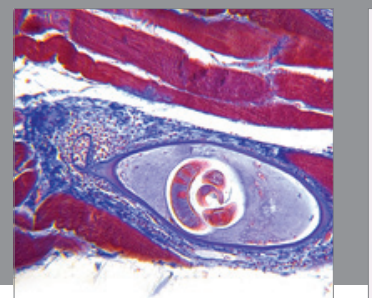

Gastroenterology

Research and Practice
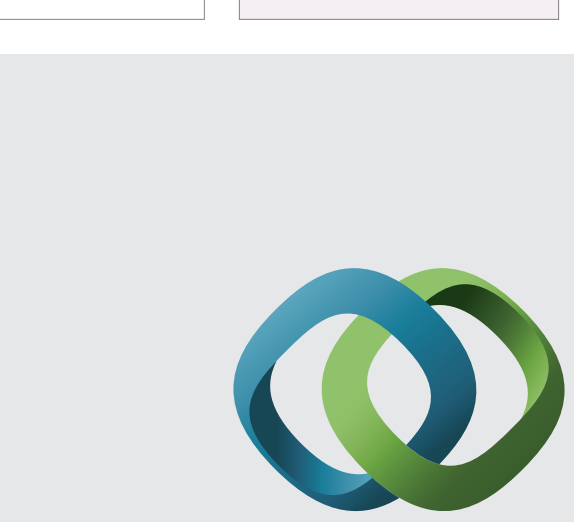

\section{Hindawi}

Submit your manuscripts at

http://www.hindawi.com
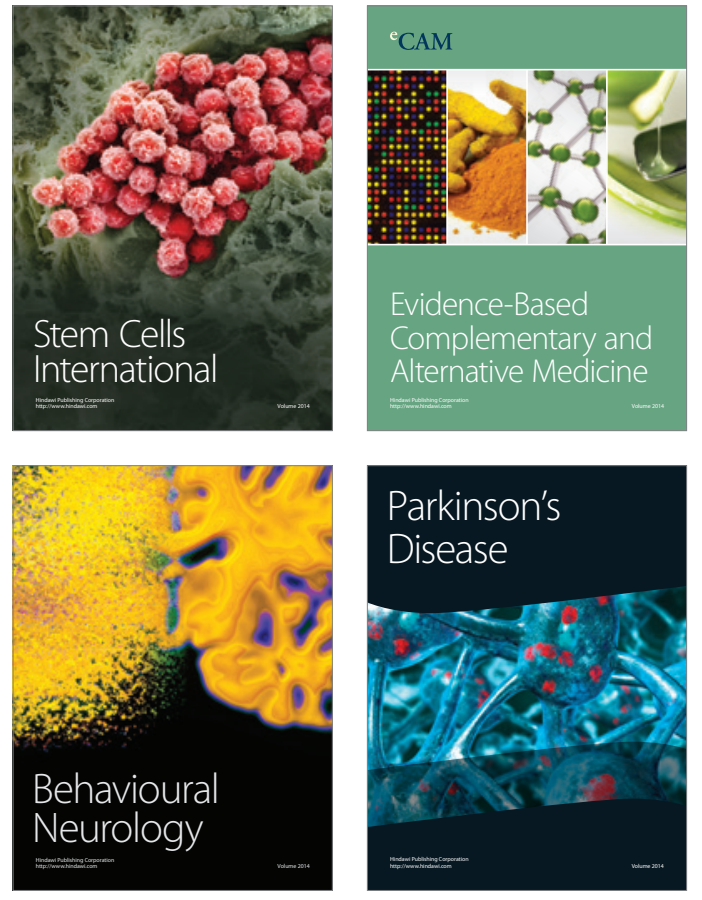
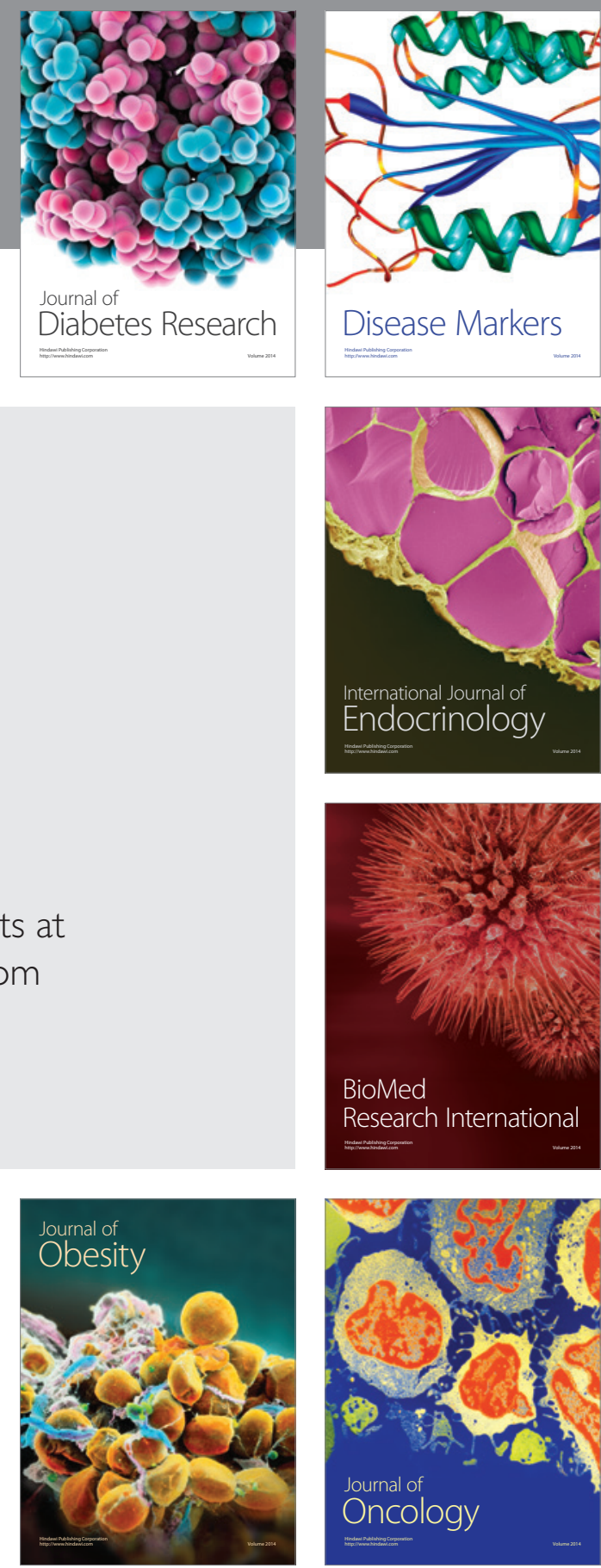

Disease Markers
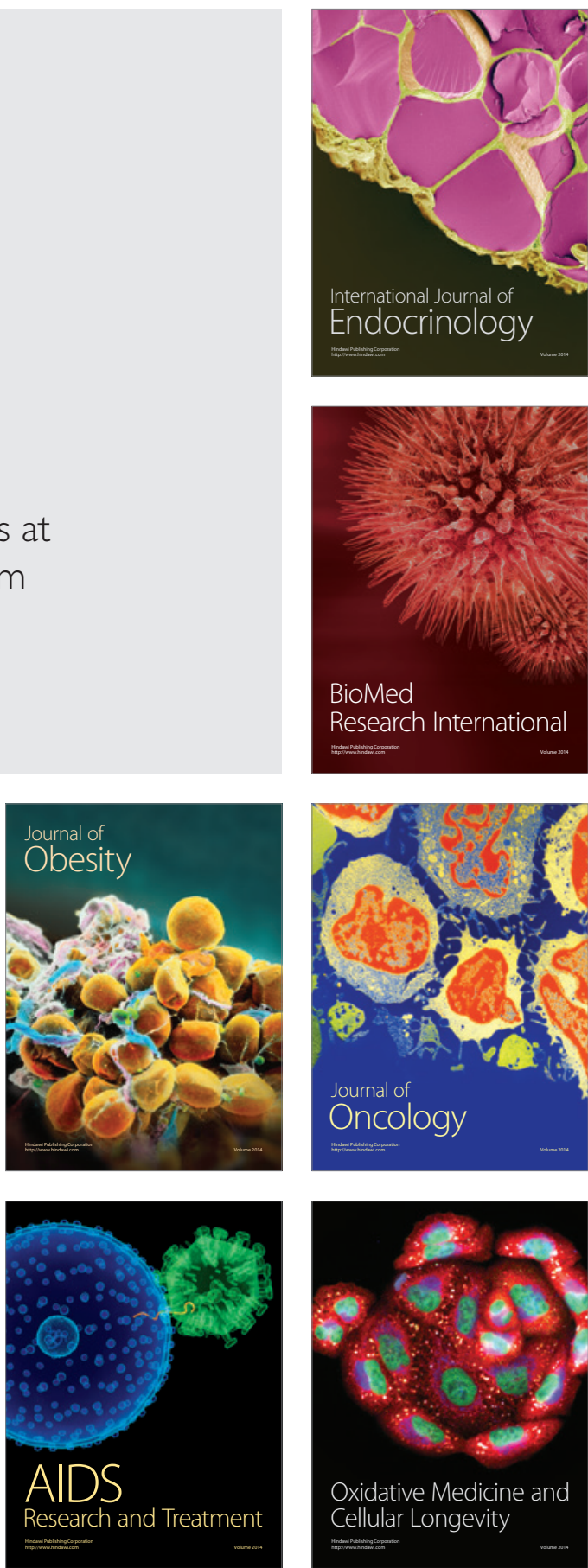